\title{
Undersea landslides: extent and significance in the Pacific Ocean, an update
}

\author{
H. J. Lee \\ US Geological Survey, 345 Middlefield Road, Menlo Park, CA, 94025, USA \\ Received: 27 May 2005 - Revised: 10 October 2005 - Accepted: 10 October 2005 - Published: 9 November 2005 \\ Part of Special Issue "Tsunami hazard from slope instability"
}

\begin{abstract}
Submarine landslides are known to occur disproportionately in a limited number of environments including fjords, deltas, canyons, volcanic islands and the open continental slope. An evaluation of the progress that has been made in understanding Pacific Ocean submarine landslides over the last 15 years shows that mapping technologies have improved greatly, allowing a better interpretation of landslide features. Some features previously identified as landslides are being reinterpreted by some as sediment waves. Previously underappreciated environments for landslides such as deep-sea trenches are being recognized and lava deltas are being found to be landslide prone. Landslides are also being recognized much more commonly as a potential source of tsunamis. Landslides that have produced tsunamis in the past are being mapped and in some cases modeled. The flow characteristics of turbidity currents produced by landslides in canyon heads have recently been monitored and the source of these failures has been identified using repeated multibeam mapping. Finally, some landslide deposits are being dated as part of assessing risk to coastal cities from landslidetsunamis.
\end{abstract}

\section{Introduction}

For the 1989 International Geological Congress, I was asked to prepare a paper on "Undersea landslides: extent and significance in the Pacific Ocean" (Lee, 1989). This paper followed over 20 years of active submarine landslide research and accordingly, presented a broad array of knowledge that had been gathered by the marine geology and geotechnical communities. With the convening of the 32nd International Geologic Congress in Florence, Italy, in 2004, it seemed appropriate to consider the progress that has been made in our understanding of submarine landslides in the Pacific Ocean over the last 15 years. The progress is truly impressive and

Correspondence to: $\mathrm{H}$. J. Lee

(hjlee@usgs.gov) indicates, in a sense, how little was known in 1989. Technology has expanded broadly and a new, unexpected level of interest in the field has developed. The present paper considers the improvements in knowledge gained over 15 years and provides a different perspective on the extent and significance of these features.

\section{Environments for submarine landslides}

Lee (1989) showed that landslides are not found evenly distributed throughout the floor of the world's oceans. Rather they tend to congregate in certain locations that Hampton et al. (1996) termed "landslide territory". Because of their unique sedimentologic and physiographic character, these areas experience slope failure to a much greater extent than other parts of the world's seafloor. These locations are as follows:

\subsection{Fjords}

Fjords with high sedimentation rates represent the environment most susceptible to failure. Fjords are drowned, glacially eroded valleys fed by sediment-laden rivers and streams that drain glaciers. These factors lead to conditions that are conducive to slope failure: steep slopes that extend to $1000 \mathrm{~m}$ or more, steeply dipping, fjord-head deltas that are formed by streams that often drain glaciers, sediment formed of low plasticity rock flour that is vulnerable to earthquake loading, and rapid sedimentation that can lead to underconsolidation (Lee, 1989; Hampton et al., 1996). Some fjord-delta deposits are so near instability that they fail during greater than average low tides. Many of these steep slopes, with weak sediment that is susceptible to cyclic loading, fail seasonally or semi-continuously (Syvitski and Farrow, 1983; Prior et al., 1986). These already weak fjordhead delta slopes episodically fail and produce catastrophic effects, such as occurred in Valdez (Coulter and Migliaccio, 1966), Seward (Lemke, 1967) and Whittier (Kachadoorian, 1965) in the 1964 Alaska earthquake or in static failure 
events, such as occurred in Kitimat Arm, Canada (Prior et al., 1982a, b).

\subsection{Active river deltas on the continental shelf}

Active river deltas are the next most likely sites for slope instability. Rivers contribute large quantities of sediment to relatively localized areas on the continental margins. Depending upon a variety of environmental factors, including wave and current activity and the configuration of the continental shelf and coastline, thick deltaic deposits can accumulate fairly rapidly. These thick, often underconsolidated and gascharged deposits can fail even on very gentle slopes $\left(<1^{\circ}\right)$ as a result of storm-wave loading or earthquakes. The locations of the major sedimentary depocenters provide some information on where undersea landslides might be expected on the continental shelf.

Deltas on the Pacific margin that show slope failures include the active deltas on the continental shelf off southern Alaska (Schwab and Lee, 1983; Schwab et al., 1987), the Yukon River delta (Clukey et al., 1980), the Frazer River delta (Luternauer and Finn, 1983) and the Klamath River delta (Field et al., 1982), which failed along a 10 to $15 \mathrm{~km}$ front during a magnitude 7.0 earthquake in 1980. Deltas of some of the major rivers that deposit large amounts of sediment along continental margins do not display geomorphic evidence of submarine landsliding, including the delta of the Columbia River (Nittrouer and Sternberg, 1981).

In China, the Huanghe is the largest source of suspended sediment and deposits about $10^{9}$ tons per year (Milliman and Meade, 1983). The modern delta exhibits many examples of sediment instability over a large area (Prior et al., 1986). The delta of the Changjing (Yangtze) River, however, does not display large-scale evidence of sediment failure features, nor does the Zhu Jiang (Pearl) River (Butenko et al., 1985; Liang and $\mathrm{Lu}, 1986$ ).

\subsection{Submarine canyon/fan systems}

Submarine canyon-fan systems serve as conduits for passing large amounts of sediment from near the continental shelf to the deep sea. Landsliding appears to be one element in the system that allows massive deposition on submarine fans to occur. According to one model (Hampton, 1972), sediment accumulations in canyon heads begin to move as coherent landslide blocks following some triggering event, such as an earthquake or storm. As the blocks move downslope, the resulting jostling and agitation causes disintegration and subsequent incorporation of surface water. The debris flow that is produced displays increasingly fluid-like behavior. As the debris flow continues on its path, further dilution by surrounding water occurs, particularly as sediment is eroded from the front of the flow. Ultimately, a dilute turbulent cloud is created that can have a density below $1.1 \mathrm{~g} / \mathrm{cm}^{3}$. The resulting turbidity current can flow for long distances (up to hundreds of kilometers) at moderate to high velocities. Other models are possible that might allow for nearly instantaneous fluidization of sands within canyon heads.

\subsection{Volcanic islands}

The existence of giant submarine landslides on the flanks of the Hawaiian Islands has been the subject of debate for at least 50 years (Normark et al., 1993). Using limited bathymetry data, Moore (1964) interpreted irregular blocky ridges extending downslope from giant amphitheaters on the submarine north flanks of Molokai and Oahu as representing giant landslides. The origin of these deposits was confirmed when a complete image of the Hawaiian Ridge was made, during GLORIA sidescan-sonar surveys of 1980's (Moore et al., 1989). In fact the GLORIA surveys showed that the Hawaiian Islands were surrounded by many giant submarine landslides. Further work (Holcombe and Searle, 1991) has shown that the Hawaiian Islands are not alone, and that many, if not most, oceanic volcanoes fail catastrophically during part of their existence.

Some component of oceanic volcanism is clearly a trigger for submarine landslides, but the nature of that component has not been determined. Most of the larger, older landslides seem to have occurred late in the shield-building phase of the host volcano (Moore et al., 1989). At this point the volcano is still producing significant magma and its stand is the highest above sea level. Many factors are present at this point and may combine to produce a trigger. Clearly there are earthquakes and significant gravitational downslope stresses resulting from the great topographic relief of the islands. However, such factors are also present on most active continental margins, but giant landslides are rare in these locations (McAdoo et al., 2000). Many volcanic islands, including Hawaii, build up over preexisting pelagic sediment bodies, often clay. This could produce a weak basal layer (Dietrich, 1988) that might contain excess pore water pressures, although the island basalts are fairly pervious and build over millions of years. Magma pressure in the rift zones has been suggested as a trigger and was evaluated by Iverson (1995) who showed that the zones of enhanced magma pressure are too small to trigger landslides wider that a few kilometers. Ground-water seepage forces provide another possible trigger (Iverson, 1995) but are probably unimportant except under rather special circumstances. Another intriguing possibility is that magma fractionates near erupting volcanoes producing a body of olivine cumulates. The resulting extensive cumulate body has a rheology similar to ice and should flow down and away from the summit of the volcano (Clague and Denlinger, 1994).

\subsection{Open continental slope}

Another common environment for undersea landsliding is the intercanyon area of the continental slope. Landslides have been reported all around the US and European margins along slopes removed from submarine canyon-fan systems (Lee, 1989; Canals et al., 2004). The observed failures are found 
near river mouths and far removed from them, as well as in both arid and humid climates. Ages of the slope failures are seldom known, so we cannot determine whether they occurred under glacial or interglacial conditions. Many were probably seismically-induced because the typical continental slopes of $5^{\circ}$ or less would be expected to be statically stable, and storm wave loading is seldom a major factor much below the shelf break (Lee and Edwards, 1986). Occurrence seems to correlate with sedimentation rate, slope declivity, seismicity, and presence of bubble-phase gas and gas hydrate, but the relationship is complex (Field, 1981). The continental slope appears to be an area of extensive mass wasting. These landslides are likely an important sediment transport mechanism, pose hazards to offshore development and may be responsible for generating tsunamis.

\section{Progress}

Research since 1989 has not greatly altered our understanding of the environments within which submarine landslides occur. However, we have greatly expanded our understanding of the morphology, processes, temporal characteristics and effects of these events. Most of this expansion has occurred as a result of new technology, particularly multibeam bathymetry, which provides continuous high-resolution images of the seafloor. In addition, progress has been made as a result of natural events that have occurred over this time span, e.g. the Papua-New Guinea landslide tsunami of 1998 and the continuing eruption of Kilauea Volcano in Hawaii.

\subsection{New technology}

Locat et al. (1999) reviewed multibeam bathymetric surveying technology and how it has been applied to mapping submarine landslides. Multibeam techniques use acoustic signals emitted from a series of transmitters mounted on the hull of a vessel (Fig. 1). Greater numbers of transmitters and higher frequencies provide more precise bathymetric information. Bathymetry data from multiple sources can also be merged together (Orange, 1999). A typical, commonly used multibeam system is the EM1000 ${ }^{\circledR}$ (Hughes Clarke et al., 1996), which works at a frequency of $95 \mathrm{kHz}$, producing a fan of 60 beams with $2.4^{\circ}$ by $3.3^{\circ}$ beam widths over a total angular swath sector of $150^{\circ}$. While the sonar can operate in water depths ranging from as little as $3 \mathrm{~m}$ to up to $1000 \mathrm{~m}$, this system is at its best for water depths between about 10 to $600 \mathrm{~m}$. The $\mathrm{EM} 3000^{\circledR}$, a more portable and recent version of the EM1000 system, can be used for water depths of less than $100 \mathrm{~m}$. The EM1000 can be mounted on a vessel as small as $8 \mathrm{~m}$ (Fig. 1a). The EM3000 and the EM1000 ${ }^{\circledR}$ systems are available from the Simrad Company. Similar systems are available from the Reson, GeoAcoustic and other Companies.

Data are collected along overlapping paths to cover the survey area. Ship speed can be as high as 14 knots without loss of accuracy depending on depth of water and ping
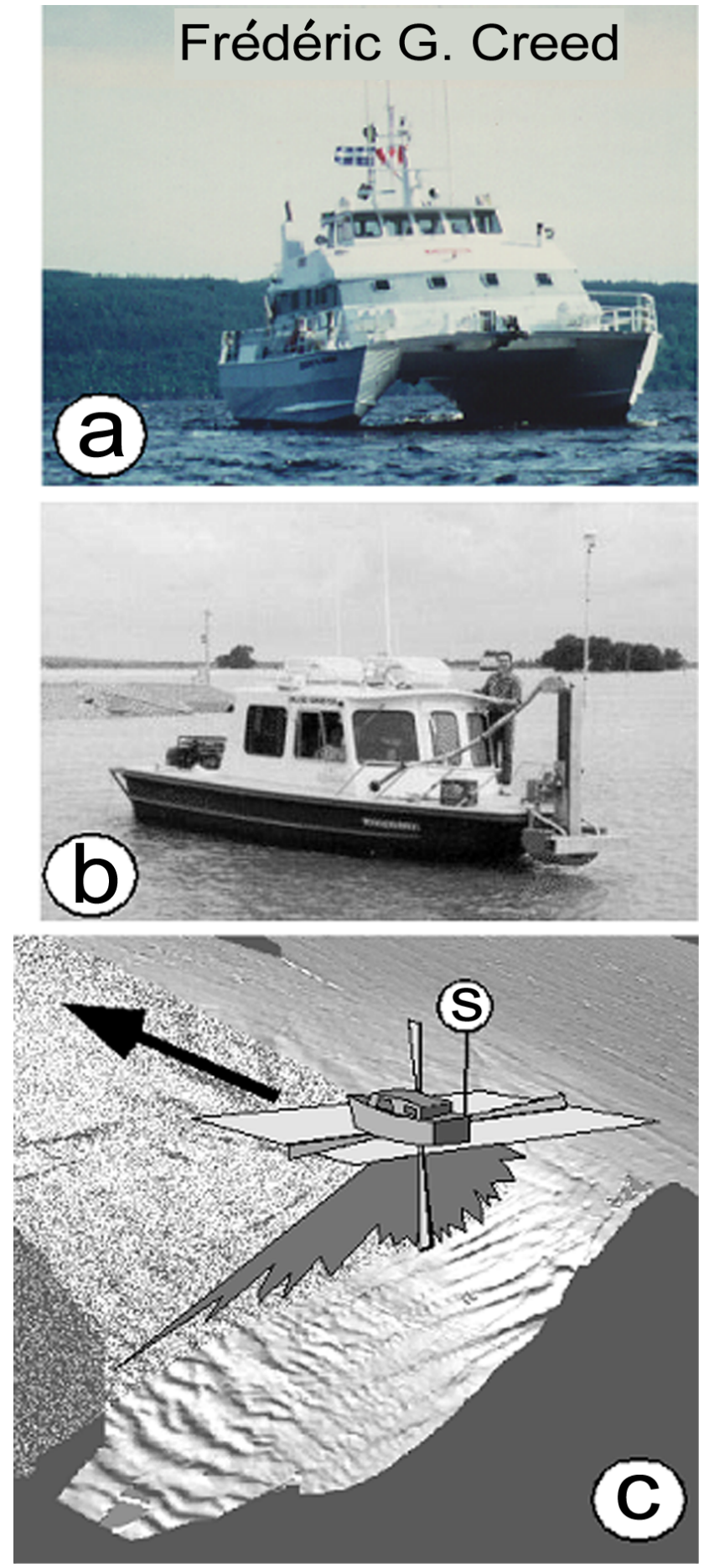

Fig. 1. Schematic of a multibeam sonar survey with vessel types (a and $\mathbf{b}$ ) and track pattern. Measurements are made of major survey characteristics (c), i.e. ship movement and position (S), with differential GPS (from Locat et al., 1999).

rate. Precise differential positioning, tide data and data correction related to ship movement are essential. In addition, the acoustic velocity is corrected by a series of acoustic profiles taken during the survey. Examples of multibeam images are given below. If repeated multibeam surveys of the same 


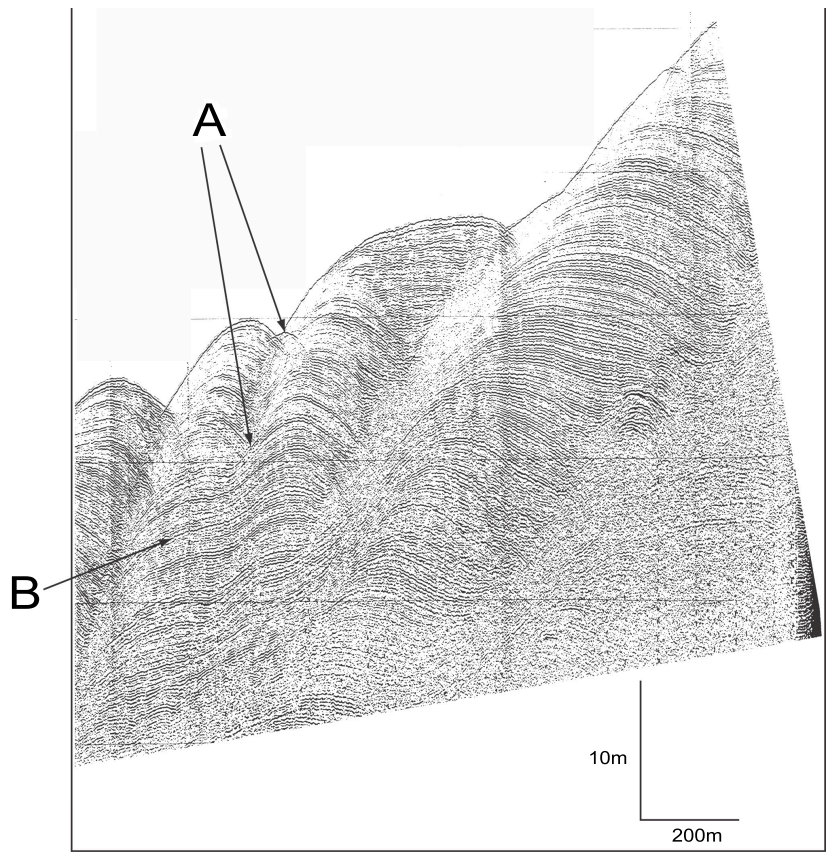

Fig. 2. Huntec sub-bottom image of wave-like features within main body of "Humboldt slide", showing: (a) A zone that separates two waves decreases in offset down-section, counter to most structural faults. (b) At depth, internal reflectors can be traced across the two units, where upsection (a) the continuity cannot be traced through the hyperbola (from Lee et al., 2002).

area are run, the differences in water depths between surveys can be calculated, identifying mass wasting and depositional events.

In addition to multibeam bathymetry, there also has been development and expanded use of improved subbottom profilers and sidescan sonar. For example Huntec DTS seismicreflection profiles and Datasonics SIS-1000 chirp sidescansonar images (Gardner et al., 1999, Fig. 2) were obtained in 1995 across the "Humboldt Slide", a feature described as a submarine landslide in Lee (1989) and many other publications. The profiles and images were of such an improved quality over earlier data that they sparked a new discussion of the basic interpretation of the feature; was it or was it not the result of a landslide?

The offshore oil industry has advanced to an even more sophisticated level in imaging geologic features using 3D seismic techniques, Such technology involves towing multiple seismic streamers behind a survey ship. As seismic sources, such as air guns, fire, the resulting acoustic energy is reflected from the seafloor surface and subbottom reflectors. The reflected energy is recorded by hydrophones on the streamers after having followed many different ray paths through a volume of the seafloor. So much data is obtained about a solid volume of the seafloor that data processing techniques can develop slices at any orientation or can follow any reflector surface, e.g. the sole of a landslide. These techniques are so expensive that they have not been applied extensively to submarine landslide research. However, in areas where
3D seismic surveys have been conducted for oil exploration or production and where landslide deposits happen to occur, the processed data can be used to describe the 3D geometry of submarine landsides (e.g. Gee, 2005). A system for obtaining high-resolution 3D imagery has been developed by IFREMER and used in the Adriatic Sea (Marsset et al., 2004).

Remotely operated vehicles (ROVs), submersibles, and towed camera systems have allowed direct contact with and detailed small-scale imaging of the features associated with submarine landslides (e.g. Morgan and Clague, 2003). With these devices, photographs and videos of small-scale landslide features can be obtained and extremely well positioned samples can be taken (within outcrops on landslide scarps and within tension cracks near the headwall). A limitation of ROV imagery is that many landslide features are so large that a close-up of a small part of the feature does not provide much information. Also, the landslides may be relatively old so that a short ROV sample on the feature may not penetrate post-landslide drape into actual landslide materials.

Oceanographic monitoring equipment has become more versatile and reliable. This allows us to deploy instruments in areas prone to turbidity currents and measure their characteristics. An example of such an application in Monterey Canyon is given below.

\subsection{Conflicts in interpretations, the "Humboldt slide"}

With much improved 3D imagery of seafloor features, we can now revisit previous studies and reevaluate interpretations. One such study that has been reevaluated is the "Humboldt Slide" near Eureka California USA. Lee (1989) listed this feature as an example of a "landslide identified by morphology". No doubts were expressed as to its nature as a landslide deposit and analyses were quoted that showed that the landslide must have been caused by an earthquake.

The US Office of Naval Research-supported STRATAFORM project (Nittrouer and Kravitz, 1996) obtained a wealth of data in the vicinity of the Eel River delta including the area of the "Humboldt slide". These data included both a multibeam image of the surface of the feature and high resolution sub-bottom profiles (Figs. 3 and 4). Both types of images showed rhythmic beds, a wave-like surface and no obvious head scarp. Because these characteristics seemed unusual relative to those usually expected for a landslide (broken beds, clear head scarp, shear planes), some scientists began to question whether the feature represented a landslide, whereas others felt that the new data provided a better look at a clear landslide feature (Gardner et al., 1999).

Those who described the feature as a landslide (Gardner et al., 1999) interpreted the subbottom profile records (Figs. 2 and 4) as showing a series of back-rotated blocks moving relatively small distances down the slope. The amplitude of motion decreases toward the toe of the feature so that the toe represents compressional folding rather than shear rupture (Fig. 4). The seaward dipping reflectors between blocks 


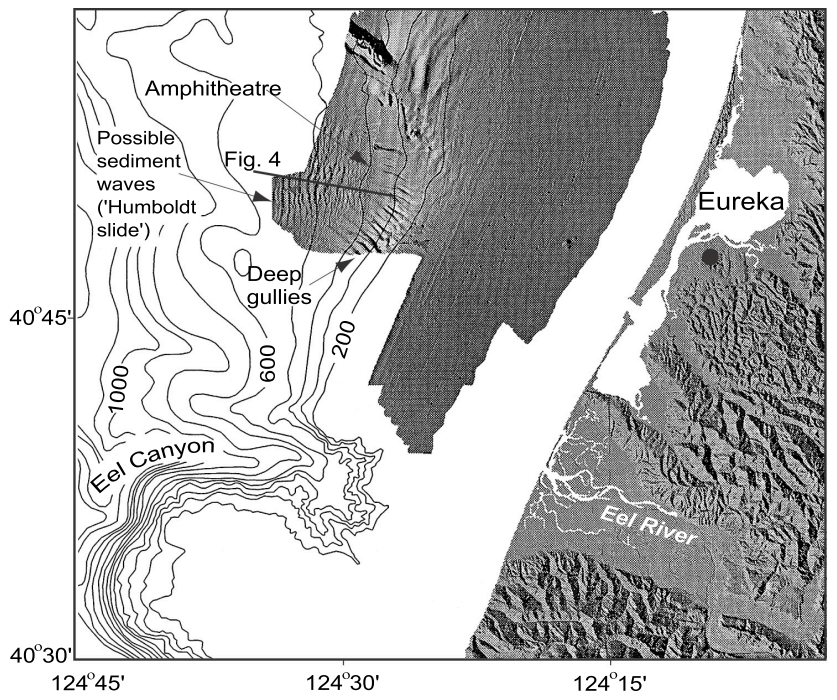

Fig. 3. Overview of Eel River STRATAFORM area (after Field et al., 1999). Data include USGS on-shore digital elevation model, as well as shaded relief bathymetry from Simrad EM-1000 multibeam system (Goff et al., 1999). Location of track line shown in Fig. 4 is identified.

(Fig. 2) are interpreted to be diffractions from abrupt edges, as opposed to a contrasting interpretation given below that they represent continuous beds.

Those who doubted a landslide origin (Lee et al., 2002) noted similarities between the characteristics of the "Humboldt Slide" and those of turbidity-current sediment wave fields described elsewhere in the world (e.g. Wynn et al., 2000). Turbidity-currents are well accepted as a cause for certain sediment-wave fields. The waves form over a long time period under the influence of a large number of turbidity currents. The exact mechanism for the formation of sediment waves by turbidity currents is not well understood although internal lee waves may play a role (Lewis and Pantin, 2002). In any case, once an initial wave-like surface has formed (perhaps because of an ancient landslide) the process of wave migration and growth is self-perpetuating (Wynn and Stow, 2002). This is because the turbidity currents will slow and deposit more material as they rise over the stoss side of a wave-like irregularity and accelerate and deposit less material on the lee side. As long as turbidity currents continue to flow the waves will build up and migrate toward the source. Lee et al. (2002) suggested that a process like this likely formed the "Humboldt slide" deposits as indicated by the following:

1. The feature contains a series of either sediment waves or landslide blocks. The upstream flanks of the waves or blocks show a more rapid accumulation of sediment than the downstream flanks.

2. Although spacing between reflections may vary as a result of (1), acoustic reflections are commonly continu-

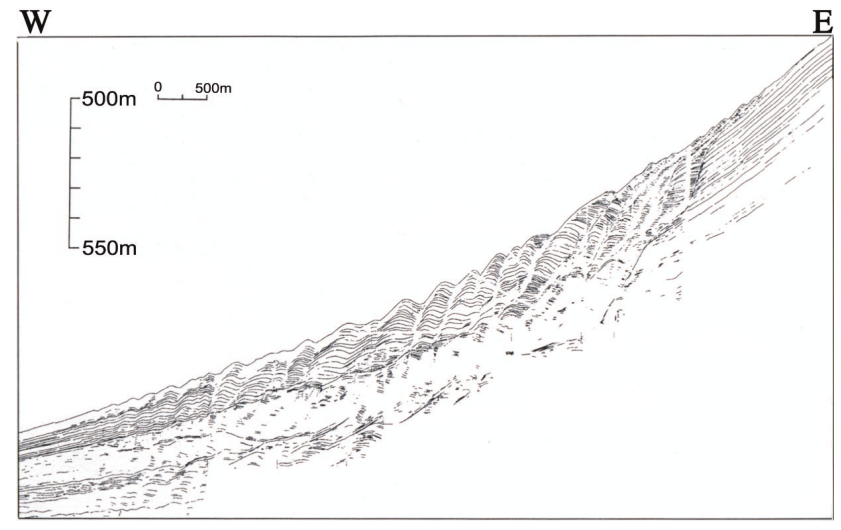

Fig. 4. Interpretation of acoustic stratigraphy of the 'Humboldt slide,' obtained using a Huntec deep-tow, seismic-reflection system operating at a narrow peak frequency of about $3.5 \mathrm{kHz}$ (after Gardner et al., 1999).

ous throughout the feature (no broken beds indicative of shear surfaces).

3. In cross section, the apparent boundaries between waves or blocks may be linear, convex upwards, or concave upwards. Listric faulting, characteristic of rotational slumps, would typically produce concave upward boundaries almost exclusively.

4. Beds can be traced through sediment-wave fields into areas of parallel reflectors. This suggests that the same sequence of turbidites can produce or not produce sediment waves depending upon changes in environmental conditions (e.g., slope gradient). This effect may be related to the range of Froude numbers over which sediment-wave formation can occur (Wynn et al., 2000)

5. The structure of internal reflectors appears similar from one wave or block to the next, that is, the waves display regularity. For example, beds within the upstream flanks tend to have generally the same dip throughout the sediment-wave field. One would expect a landslide to be more chaotic.

6. The wavelength and wave height commonly diminish toward the edges of the feature.

7. There is no headwall scarp or a zone of evacuation, such as one usually finds in a landslide.

Some of these characteristics are illustrated in Fig. 2, and others are given by Lee et al. (2002). Lee et al. (2002) suggested that other features worldwide that had been previously identified as landslides were actually sediment wave fields including the "Malaspina slump" off the coast of southeast Alaska (Carlson, 1978) and several features off Europe. In general, there is not consensus in the community about seafloor features that have a wave-like morphology but some characteristics of landslides. Both origins need to be considered when evaluating new data. 


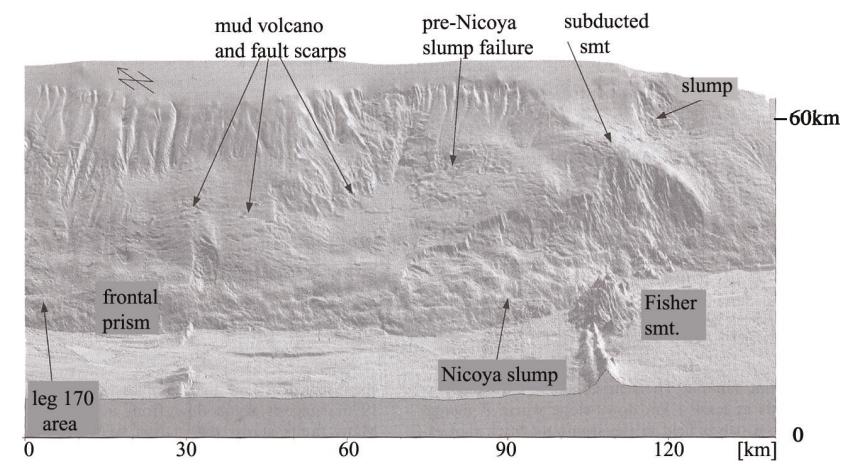

Fig. 5. A variety of mass wasting features in the Middle America Trench off Costa Rica. Note the association of the Nicoya slump with seamounts (such as the Fisher Seamount which is nearing the trench wall) that are subductrd beneath the frontal prism (from von Huene et al., 2004).

\subsection{Previously underappreciated environment: deep-sea trenches}

Scientists have long recognized that deep-sea trenches, characteristic of subduction zones, are locations of intense seismicity and irregular topography. However, because of the difficulty in performing high-resolution surveys in deep water, little was known about the occurrence of landslide features along the sides of trenches. Recent multibeam mapping efforts and the occurrence of landslide tsunamis in areas such as Papua New Guinea have shown that trenches are important locations for large and potentially tsunamigenic submarine landslides.

Von Huene et al. (2004) described slope failures in two settings along the sides of the Middle America Trench. Both along the Costa Rica and Nicaragua margins, numerous landslide deposits are found having a variety of sizes and other characteristics. Von Huene et al. (2004) described two major mechanisms that cause slope failures in trenches along these types of margins: (1) subduction of lower plate relief, particularly seamounts and (2) increase in slope angle from subduction erosion. Subduction of seamounts is perhaps the most dramatic (Fig. 5). Off Panama and Costa Rica about $40 \%$ of the oceanic crust is covered by seamounts. These seamounts in turn are typically $2-4 \mathrm{~km}$ high and $20 \mathrm{~km}$ in diameter and are translated into the trenches by means of plate tectonic processes. As the seamounts reach the floor of the trenches they come into contact with the inner trench wall or frontal prism. Considerable evidence, including clustered earthquakes beneath the shelf and local uplift along the coast, suggests that, rather than simply being sheared off, the seamounts appear to remain attached to the underthrust plate for more than $100 \mathrm{~km}$ landward of the trench axis. As the seamounts pass through the frontal prism, they cause massive fracturing, changes in relief, changes in physical properties and changes in fluid pressures and fluid flow (Fig. 6). All of these factors contribute to enhanced slope failure. Although the high degree of seismicity in subducion zones probably

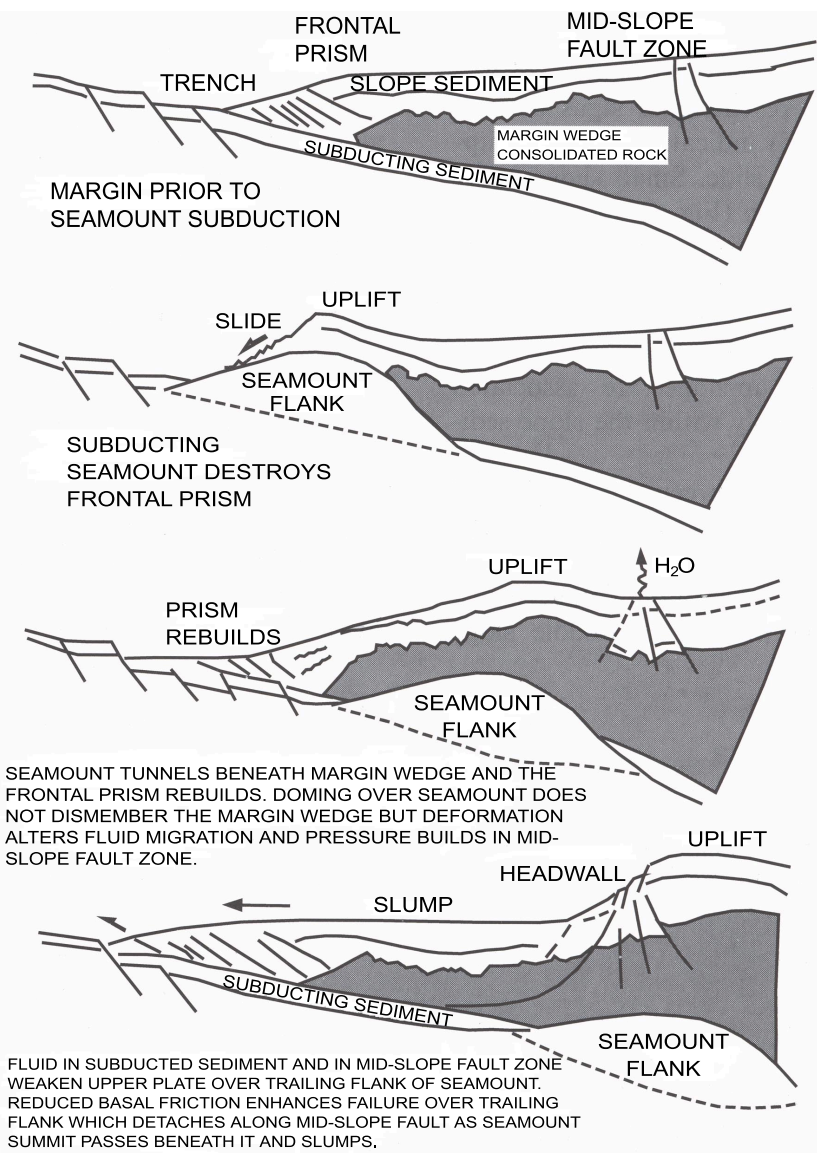

Fig. 6. Diagrammatic sections across the Nicoya Slump showing a sequence of slide development (from von Huene et al., 2004).

ultimately triggers slope failures, the slope conditioning factors associated with seamount subduction likely cause these locations to be much more prone to failure.

Subduction erosion is a more subtle effect than subduction of seamonts. Subduction erosion refers to removal (scraping off) of the bottom of the frontal prism (landward slope) of the trench by the subducting plate. When this occurs, the prism rotates into the trench steepening the slope (Ranero et al., 2000). In an area of high seismicity, steepening of slopes tends to increase the likelihood of slope failure. For the Middle America Trench, von Huene et al. (2004) felt that the area off Nicaragua, which also contains numerous landslides but involves few subducting seamounts, may have been partly destabilized by subduction erosion.

McAdoo et al. (2004) reviewed many of the world's convergent margins, most of which are found in the Pacific, and determined that they vary considerably in the roughness of their slopes and extent of well-preserved submarine landslides. The Nankai and Kodiak margins have smooth, highly eroded lower slopes with little evidence of large, well-preserved submarine landslides. In contrast, the Sanriku, Nicaragua, and Aleutian margins have noticeable offshore landslides. Likewise the Cascadia margin has a number of large, well-preserved landslides but also contains 

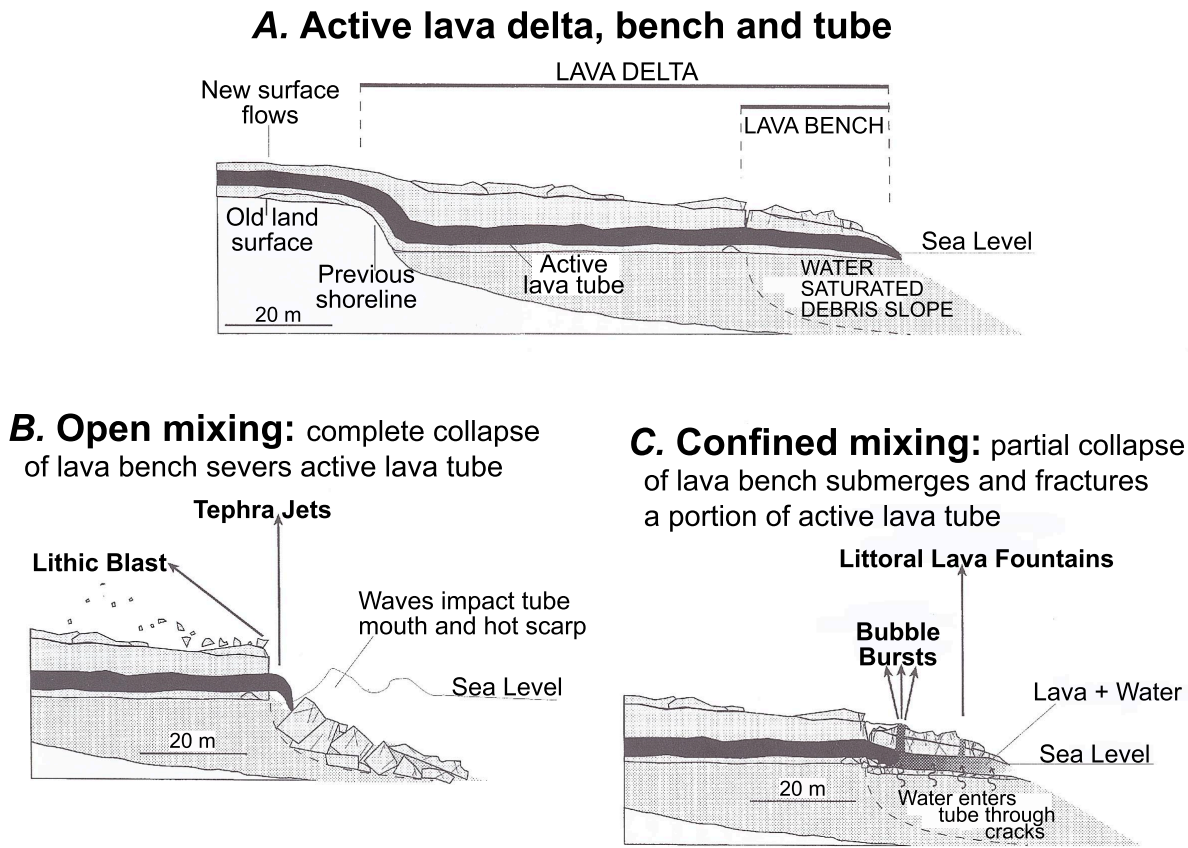

Fig. 7. Hypothetical cross section of a lava delta and bench showing the locations of lava bench collapses and hydrovolcanic explosions. (a) Volcanic sands build a submarine debris slope that is subsequently capped by lava flows, (b) Ultimately the lava bench can collapse completely or (c) partially (from Mattox and Mangan, 1997).

numerous steep $\left(\sim 20^{\circ}\right)$ depositional slopes that have not failed. McAdoo et al. (2004) concluded that the morphology of the trench slopes bordering convergent margins is indicative of the potential for producing large tsunamis.

\subsection{Previously underappreciated process: lava-delta collapse}

When Lee (1989) was written, the marine geology community was just beginning to accept the idea that truly gigantic subaerial/subaqueous landslides had taken away significant parts of the Hawaiian Islands and deposited the remains on the seafloor over areas that extended up to $200 \mathrm{~km}$ offshore (Moore et al., 1989). Some of these landslides are estimated to have had volumes of about $5000 \mathrm{~km}^{3}$, making them among the largest on earth (Lipman et al., 1988). They most certainly would have generated devastating tsunamis around the Pacific Rim. However, the average periodicity for the major landslide events is in the order of 100000 years, lessening the risk of a catastrophic event in the near future.

During the early 1990's a more common but less catastrophic type of slope failure became better understood around the Hawaiian Islands: the failure of lava deltas built out when erupting volcanoes introduce large volumes of lava into the ocean (Mattox and Mangan, 1997). The longest continuous eruption of a Hawaiian volcano, the Puu Oo eruption of Kilauea, began in 1983 and continues to the present. When lava from the eruption first reaches the ocean, the flows drip over old sea cliffs or spread out along established beaches. The lava is quenched when it enters the surf zone and shatters into glassy, angular fragments, forming a type of sand. The fragments build out a loose submarine slope. Later, subaerial flows build out on this slope, forming lava deltas (Fig. 7), which eventually can build out hundreds of meters seaward. As the flow field matures, a tube system is established within the delta and lava enters the ocean at a few discrete points.

Lava deltas often advance rapidly for a few weeks and then slow as the leading edge moves into deeper water.. The tube streams may consolidate into a single, well-defined tube entry. The leading edge of the delta then becomes prone to failure. Cracks form parallel to the coast and sections of the delta, extending perhaps $40 \mathrm{~m}$ seaward, collapse catastrophically into the ocean. Such collapses can occur repeatedly, gradually forming a steep scarp bounding the edge of the deltas. Almost all delta collapses lead to explosive mixing of seawater and lava.

The process of lava-delta collapse is clearly a hazard to visitors and provides insight into the formation of the Hawaiian Islands. The mixture of coarse, angular sand and broken lava benches forms a loose, weak structure for the islands, which can ultimately lead to much larger scale failures.

\subsection{Previously underappreciated effects: landslide tsunamis}

Scientists have understood for some time that coastal and marine landslides can generate potentially damaging tsunamis. For example, the 1975 landslide in Kitimat Fjord in British Columbia, Canada, was triggered by a low tide and produced waves up to $8,2 \mathrm{~m}$ in height causing considerable damage (Lee, 1989; Murty, 1979; Prior et al., 1982a). Likewise, the 1964 Alaska earthquake triggered submarine landslides 


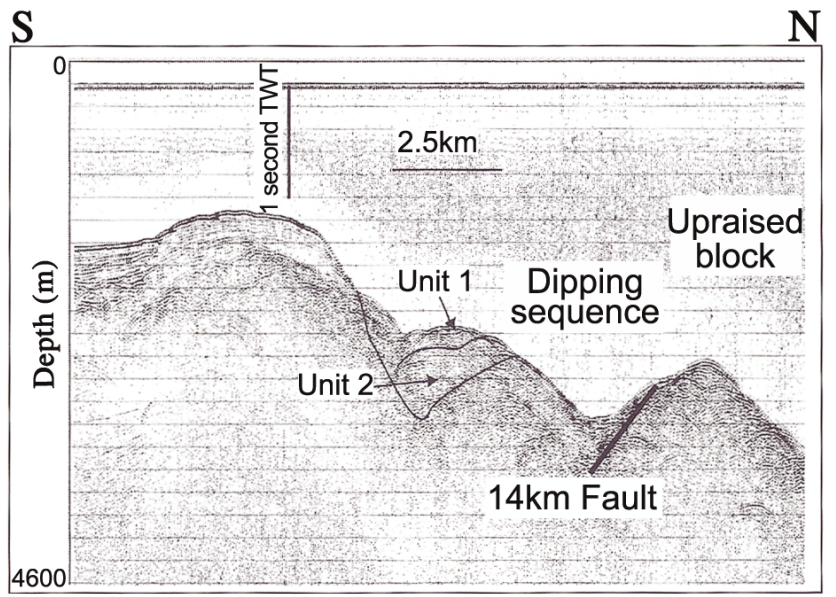

Fig. 8. Features interpreted to be the slumps that were responsible for the damaging tsunamis that occurred in Papua New Guinea in 1998 (from Tappin et al., 2003).

in many fjords, which in turn caused catastrophic tsunamis that damaged or destroyed coastal communities (Lee, 1989; Plafker et al., 1969; Hampton et al., 1993).

The 1998 Papua-New Guinea tsunami was perhaps the most significant event defining the importance of offshore landslides in causing damaging tsunamis (Tappin, 2005 ${ }^{1}$, Tappin et al., 2001; Synolakis et al., 2002). This is perhaps partly because there has been an argument as to whether the tsunami was the result of an earthquake or an offshore slope failure. The maximum height of the tsunami, 10-15 m, is well known as is the scale of damage resulting from the tsunami: 2000 people killed and many villages damaged or destroyed. Also well known is the association of the tsunami with a magnitude 7.1 earthquake (Tappin et al., 2001). What has been in dispute is whether the earthquake itself caused the tsunami or if the earthquake caused a submarine landslide, which in turn caused the tsunami. Onshore investigations of the tsunami height distribution and estimates of the relative timing of the earthquake and the tsunami indicate that the local tsunami source was directly offshore and not the a direct result of the main earthquake rupture. Also, offshore surveys, incorporating multibeam imagery, subbottom profiling, sediment cores, and ROV dives, showed an apparent landslide deposit (Fig. 8) and characteristic landslide morphology in approximately the correct location to have produced the observed tsunami (Tappin et al., 2003, Tappin, $2005^{1}$ ).

The 1998 Papua New Guinea tsunami brought many new and enthusiastic investigators into the field of submarine landslide research. International meetings have been held and a variety of special publications have been produced (Yalciner et al., 2003; Tappin, 2004; Tappin and Lee,

\footnotetext{
${ }^{1}$ Tappin, D. R.: The Papua-New Guinea tsunami: anatomy of a catastrophic event, Nat. Hazards Earth Syst. Sci., in preparation, 2005.
}
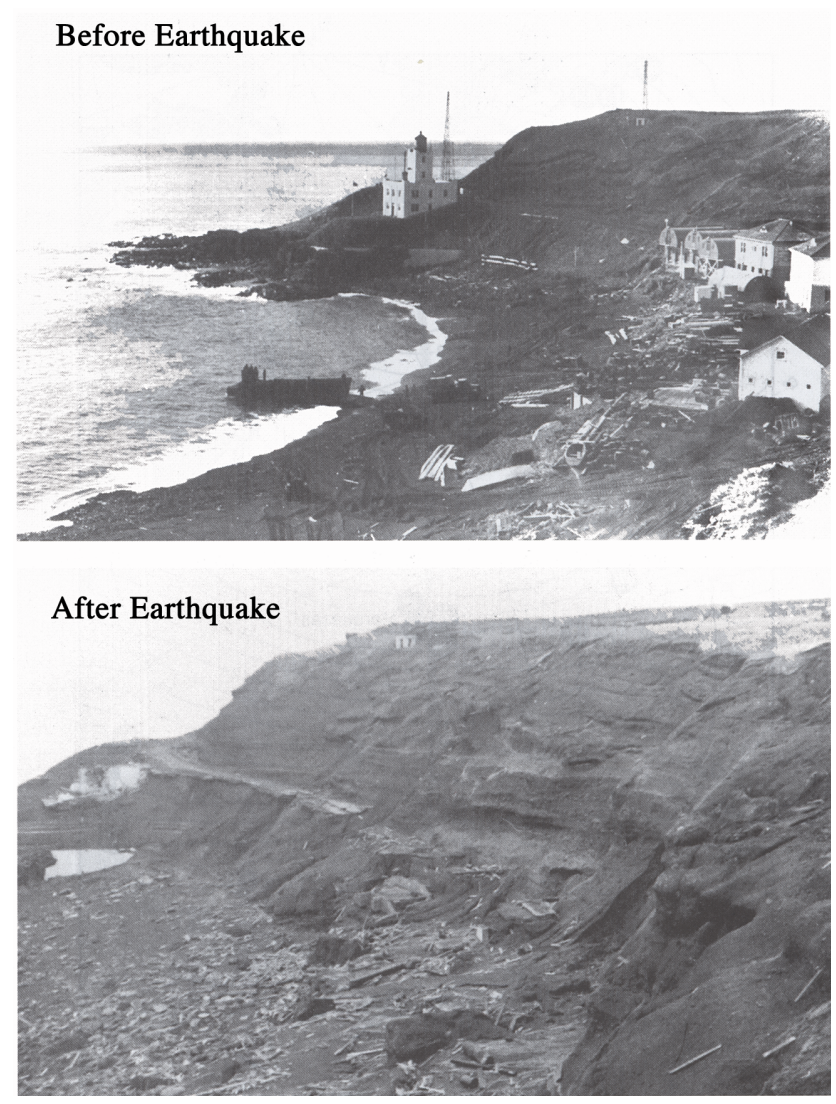

Fig. 9. The Scotch Cap Coast Guard Station on Unimak Island, Alaska, before and after the 1946 earthquake and tsunami.. Maximum runup was $42 \mathrm{~m}$. The large runup has never been satisfactorily explained (from Fryer et al., 2004).

$2005^{2}$ ). These interactions have led far beyond the Papua New Guinea tsunami into reevaluations of anomalous historic tsunamis and a search for large landslide deposits near developed coastlines. If one of these landslides were to recur, the resulting tsunami would likely cause major damage to coastal cities or offshore facilities.

One example of a revisited anomalous tsunami is the great 1946 tsunami associated with an earthquake in the Aleutian forearc. The earthquake was not particularly large $\left(M_{S}=7.1\right)$, but it produced a disproportionately large tsunami which killed 167 people (Fryer et al., 2004). The tsunami was very directional and projected its waves along a beam perpendicular to the Aleutian arc all the way to Antarctica. In the nearfield the tsunami had very high runup $(42 \mathrm{~m}$ at the Scotch Cap lighthouse, Fig. 9) but decayed rapidly laterally. Fryer et al. (2004) suggested that no earthquake source could explain the narrow beam of the farfield and the rapid lateral attenuation in the nearfield. Fryer et al. (2004) and Okal et al. (2003) concluded that the characteristics of the tsunami suggest an earthquake-triggered landslide rather than a purely tectonic

\footnotetext{
${ }^{2}$ Tappin, D. R. and Lee, H. J.: Submarine landslides and tsunami: an historical perspective, Nat. Hazards Earth Syst. Sci., in preparation, 2005.
} 


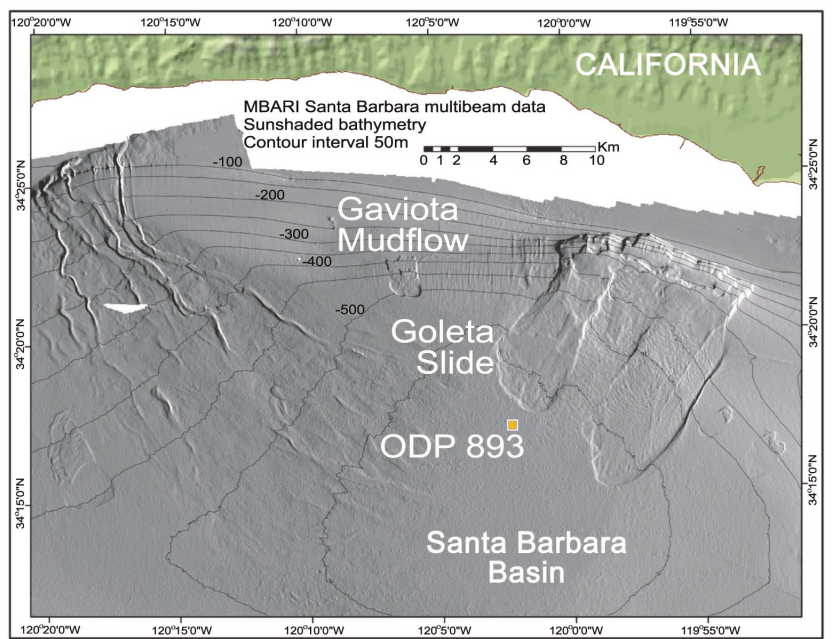

Fig. 10. Multibeam image of mass transport complexes in the Santa Barbara Basin (courtesy of the Monterey Bay Aquarium Research Institute). The figure shows the Gaviota mudflow, the multi-lobed Goleta slide and the location of ODP site 893 (from Lee et al., 2004).

source. However, the deposits from a large landslide in the area that could be assigned a very recent date have not been identified.

The search for landslide deposits near population centers that may suggest a future landslide tsunami hazard has focused on southern California, USA, where there are large coastal cities and many popular beaches. Two areas that have received particular attention are the Palos Verdes landslide complex off the Palos Verdes Peninsula and the Los AngelesLong Beach Harbors (Bohannon and Gardner, 2004; Locat et al., 2004; Normark et al., 2004; Lee et al., 2003) and the Goleta/Gaviota landslide complexes in the Santa Barbara Channel (Eichhubl et al., 2002, Edwards et al., 1995, Lee et al., 2004, and Greene et al. this volume). The Goleta/Gaviota and Palos Verdes complexes (Figs. 10 and 11) include multiple events extending back 10s of thousands of years. The most recent large-scale failure episodes in both locations occurred in the early Holocene and involved approximately $0.5 \mathrm{~km}^{3}$ of failing material (Lee et al., 2004). Locat et al. (2004) estimated that the most recent episode of the Palos Verdes landslide complex involved a catastrophic failure with peak velocities of over $40 \mathrm{~m} / \mathrm{s}$, generating a tsunami with an initial height of $10 \mathrm{~m}$ or more. Greene et al. (2005) predict that the most recent failure of the Goleta complex might have produced tsunami wave runup in the order of $12 \mathrm{~m}$ near Coal Oil Point and Goleta Point, west of Santa Barbara, California, USA.

\subsection{New types of measurements are being made}

Technological improvements allow us to make measurements that were previously impossible or very difficult. An example of the application of improved measurements being applied to submarine mass wasting events is the re-
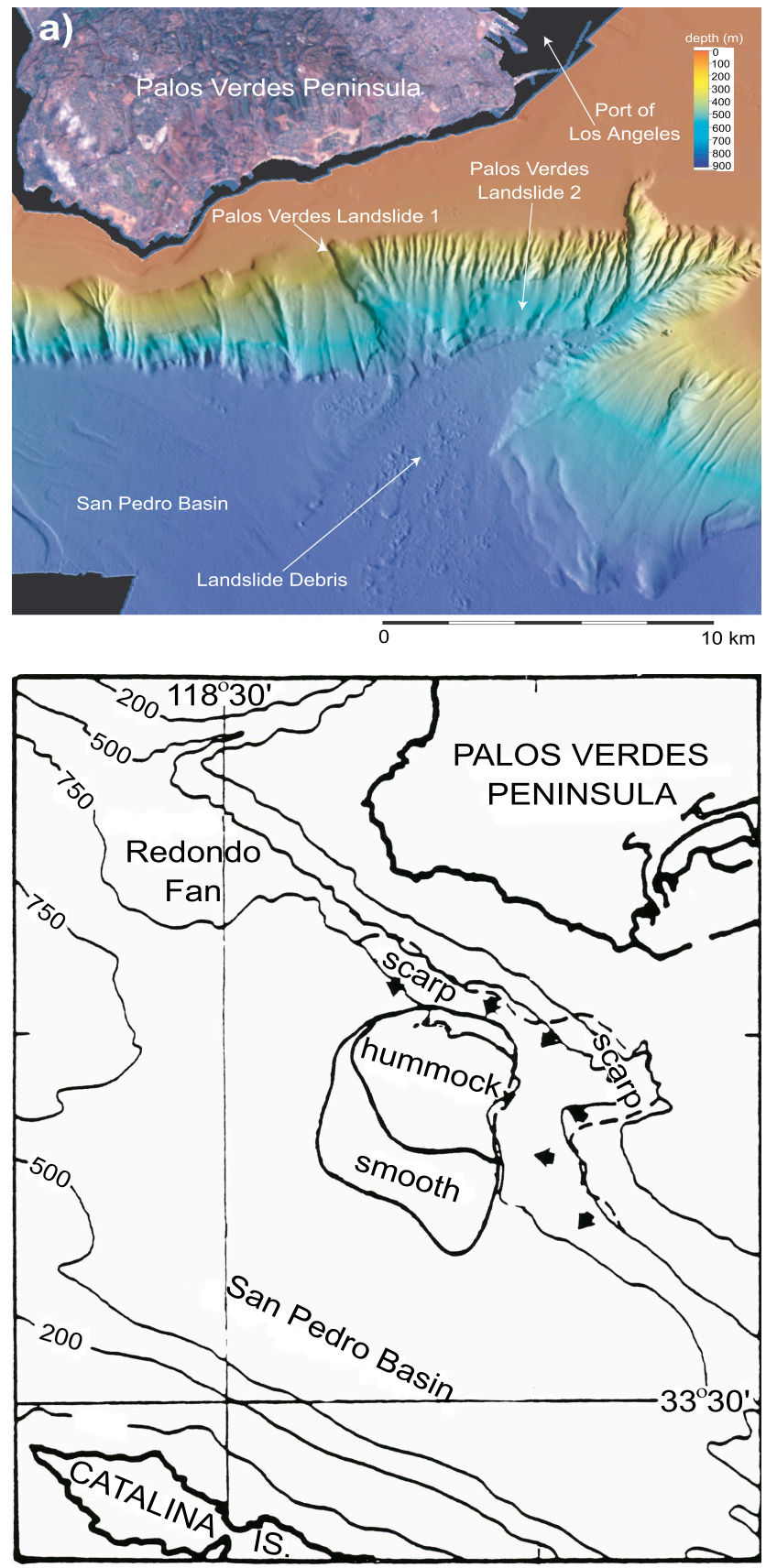

Fig. 11. (a) Shaded relief, multibeam imagery of the Palos Verdes margin, near Los Angeles, Southern California. The image shows a large landslide complex containing significant gullying and two recent failures, the Palos Verdes Landslides 1 and 2 (after Lee et al., 2003). (b) Interpretations of the same landslide complex area based on surveys using older technologies (Gorsline et al., 1984).

cent capture of turbidity-current-velocity-structure information within Monterey Canyon, offshore central California (Xu et al., 2004). Attempts to measure the characteristics of turbidity currents and mass wasting events in action have been made repeatedly over the last 30 years. Some of these efforts have met with success including studies of turbidity currents in Bute Inlet, a fjord in British Columbia (Prior et al., 


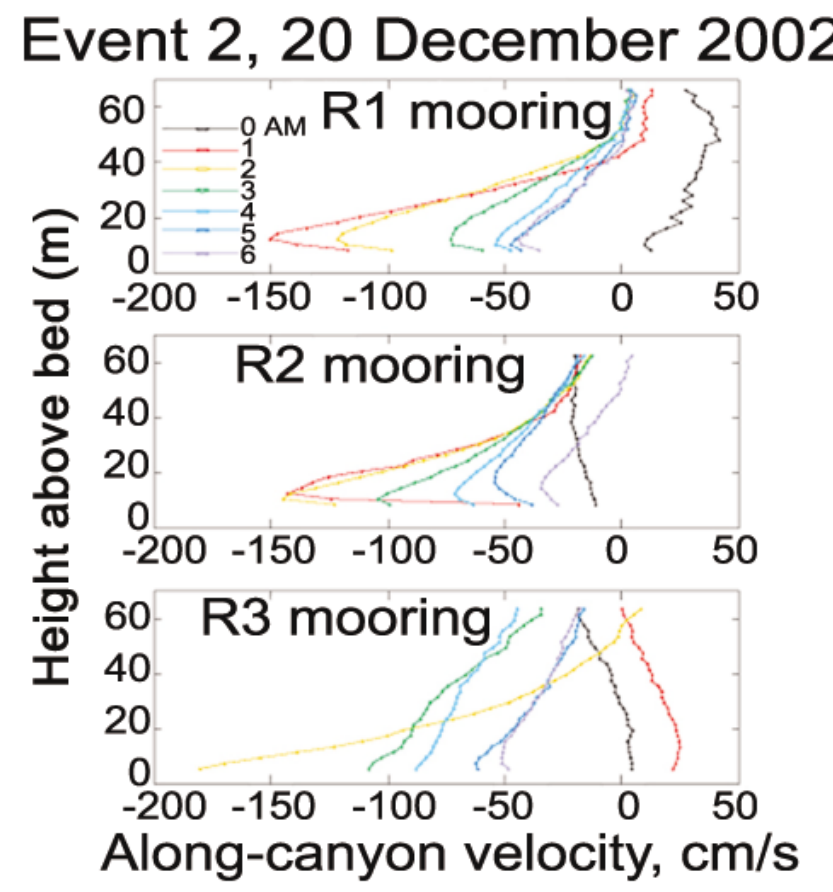

Fig. 12. Hourly vertical velocity profiles of a turbidity current recorded at three mooring locations in Monterey Canyon. The vertical scale is height above the canyon floor in meters (from $\mathrm{Xu}$ et al., 2004).

1987; Bornhold et al., 1994). However, many have met with failure, including an attempt to generate a landslide and turbidity current by blasting (Syvitski, 1992). Also, instruments have been installed in deep-sea canyons only to be destroyed or seriously damaged by the passage of the turbidity currents that they were intended to monitor (Paull et al., 2003).

During a recent deployment of 3 oceanographic moorings in Monterey Canyon (Xu et al., 2004), the passage of a total of four turbidity currents was recorded over a 12 month period. Two events coincided with storms that produced the greatest swells and stream flows during the deployment and one coincided with dumping of dredge material at the head of the canyon. One event did not appear to be associated with any unusual occurrence. The records show the detailed velocity structure as a function of time for the range of water depths extending from the seafloor to $60 \mathrm{~m}$ above the seafloor (Fig. 12). A maximum velocity of almost $2 \mathrm{~m} / \mathrm{s}$ was recorded with flow durations of a much as $8 \mathrm{~h}$. Such results were previously unavailable and should provide example data for testing turbidity current models.

In addition to current and other oceanographic measurements, two serial multibeam surveys of the head of the canyon were conducted fortuitously by the California State University at Monterey Bay (Smith et al., 2005) bracketing the period of the observed turbidity currents (Fig. 13). By differencing these two bathymetric surveys, the investigators could estimate possible sources and volumes of material that may have been involved in the turbidity current flows. The surveys also indicated a field of sediment waves lying along

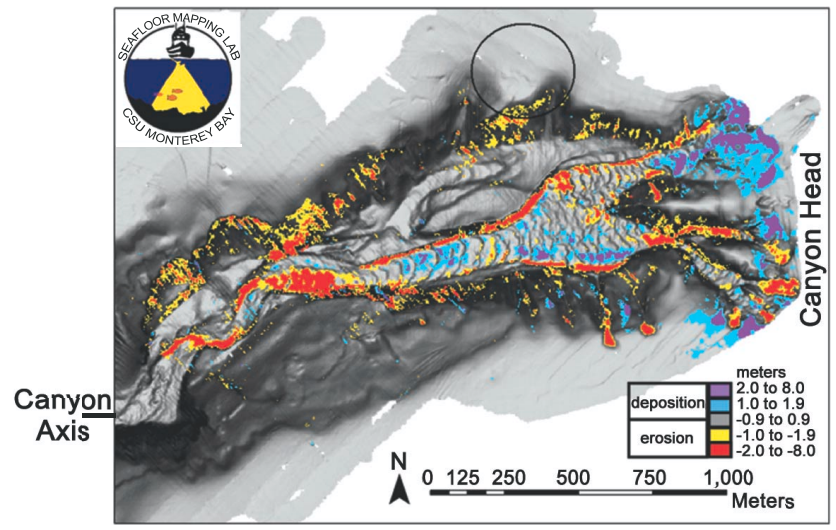

Fig. 13. Raster subtraction of two multibeam images in the head of Monterey Canyon obtained in September 2002 and March 2003. Channel widening and ìpoolî scour is present in the floor of the canyon. Some distributaries in the head of the canyon (SE) show sediment removal during this time period whereas others (NE) show sediment storage (from Smith et al., 2005). Areas of sediment removal are likely the source of the turbidity current shown in Fig. 12.

the bottom of the canyon. These waves could be related to the passage of the recorded turbidity currents or they may be related to internal wave or other water current motion within the canyon.

In a related study of sediment transport in Monterey Canyon, Paull et al. (2005) obtained a series of very well positioned vibracores from an ROV. These were navigated within a multibeam image and showed that a veritable "river of sand" exists on the canyon floor. The sand apparently moves varying distances into the canyon on a regular basis during successive gravity-flow events. These sand deposits likely provide a reservoir for the occasional enormous gravity-flow event that periodically covers the associated submarine fan.

\subsection{Much improved images}

As has been seen above greatly improved bathymetric mapping, made possible through multibeam technology, has revolutionized the field of submarine landslide investigations over the last 15 years. Additional examples are provided by images now available in Resurrection Bay, Alaska, Commencement Bay, Washington, the seafloor north of Oahu and Molokai, Hawaii, and within submarine canyons.

1. Resurrection Bay, Alaska. The community of Seward, situated at the head of Resurrection Bay along the east side of the Kenai Peninsula was particularly hard hit by the great Alaskan earthquake of 1964 (Lemke, 1967; Hampton et al., 1993). Much of the damage and most of the 13 deaths in Seward were related to coastal and seafloor slope failure and the generation of local tsunamis (Lee et al., 2003). Although some information about the extent and morphology of the submarine and coastal landslides has been available for some time, it was not until a recent multibeam survey of the bay 

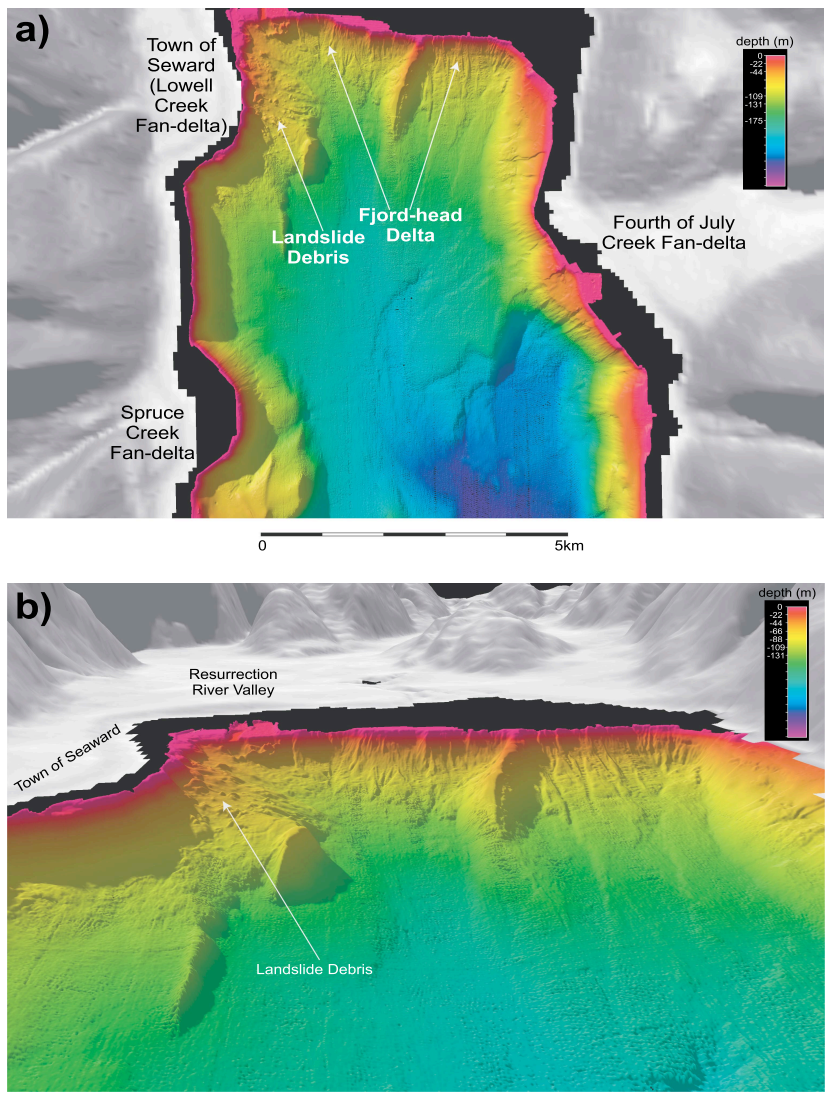

Fig. 14. Shaded relief multibeam imagery of the head of Resurrection Bay, Alaska, showing map (a) and oblique (b) views. The oblique view has a vertical exaggeration of 3 ; the base of the oblique image is $2500 \mathrm{~m}$ across (Lee et al., 2003).

that the detailed character of the deposits became known (Fig. 14). The resulting imagery shows the front of the major fjord-head delta of the Resurrection River extending completely across the northern end of the Bay. Within the area mapped in Fig. 14a, the fronts of three smaller fan deltas produced by tributary creeks (Lowell Creek, Fourth of July Creek, and Spruce Creek) can also be identified. The town of Seward was built on one of these fan-deltas (Lowell Creek), and it was the face of this feature that failed catastrophically in 1964, removing significant parts of the town's infrastructure. The remains of this failure appear as blocky debris extending offshore for about $500 \mathrm{~m}$ (Fig. 14b). Some of the blocks are 10 to $15 \mathrm{~m}$ high. The other two small fan deltas (Fourth of July Creek and Spruce Creek) do not show comparable blocky debris. The local tsunamis created in 1964 must have been related in part to the failure of the Lowell Creek fan-delta and the production of the blocky debris. Other failures throughout Resurrection Bay may have contributed to the tsunamis.

2. Commencement Bay, Washington. The Puyallup River flows into Commencement Bay near Tacoma, Washington, carrying much of the meltwater from the glaciers
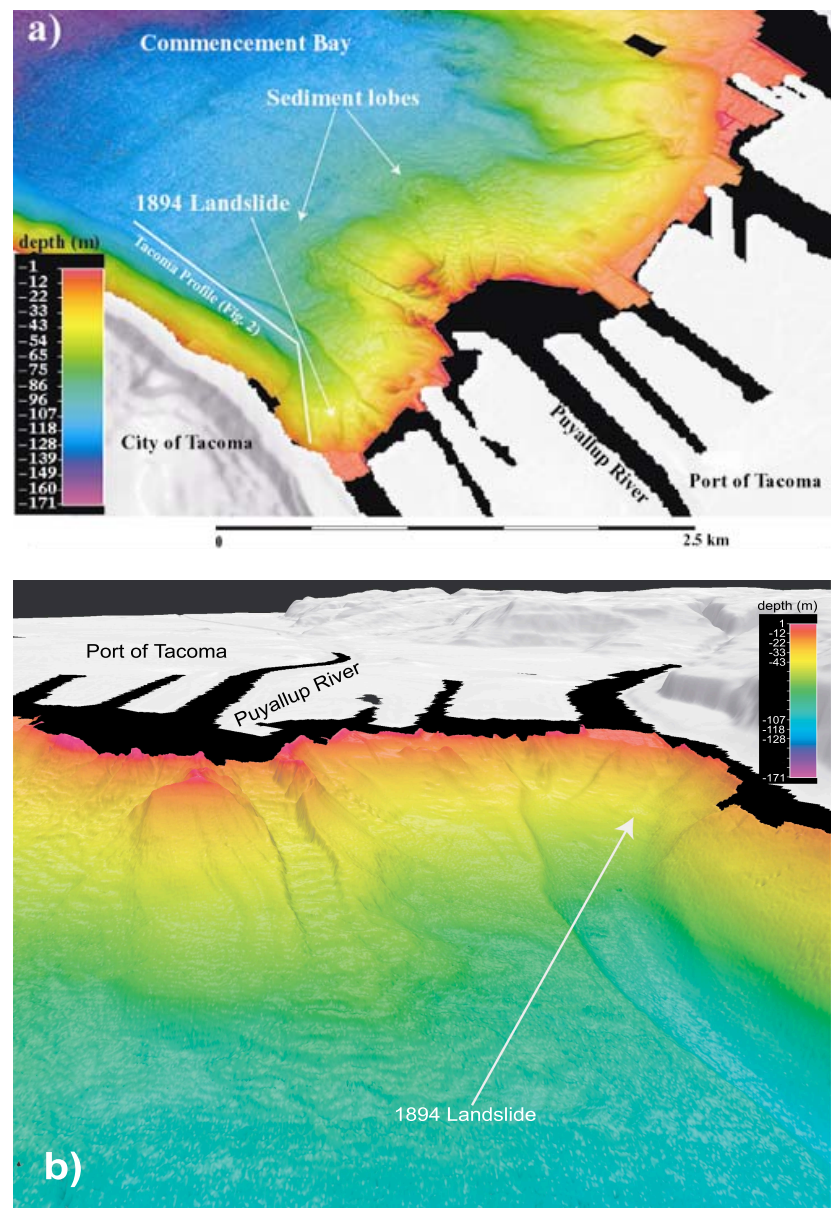

Fig. 15. Shaded relief multibeam imagery of the head of Commencement Bay, Washington, showing map (a) and oblique (b) views. The oblique view has a vertical exaggeration of 3 ; the base of the oblique image is $900 \mathrm{~m}$ across (Lee et al., 2003).

of Mount Rainier, including large quantities of glacial silt. The rapidly prograding delta has advanced an average of $2 \mathrm{~km} / 10^{3}$ years over the last 6000 years, leading to high excess pore water pressures and an increase in the likelihood of failure. At least two failures (1894 and 1992) of the delta front occurred in historic time (Gardner et al., 2001) under aseismic conditions. The 1894 failure resulted in a tsunami that caused the loss of railway track, roadway, and several buildings and led to two deaths.

A multibeam bathymetric survey of Commencement Bay (Fig. 15) was conducted in 2001 (Gardner et al., 2001), allowing the identification of a number of failure features, including a 2-km-long channel in the southwestern portion of the Bay that almost certainly corresponds to the 1894 failure. The head of the channel (identified as "1894 landslide" in Fig. 15) is $450 \mathrm{~m}$ wide and shows little remaining failure material. The landslide debris must have fully mobilized, flowed down the mapped channel, and dispersed along the floor of Puget Sound. 
(a)

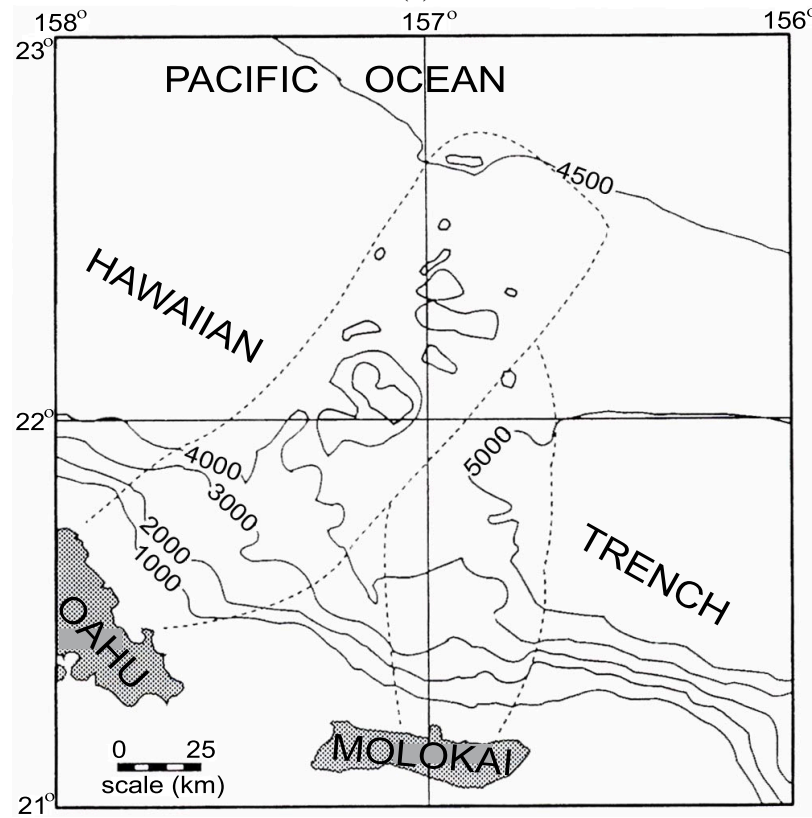

(b)

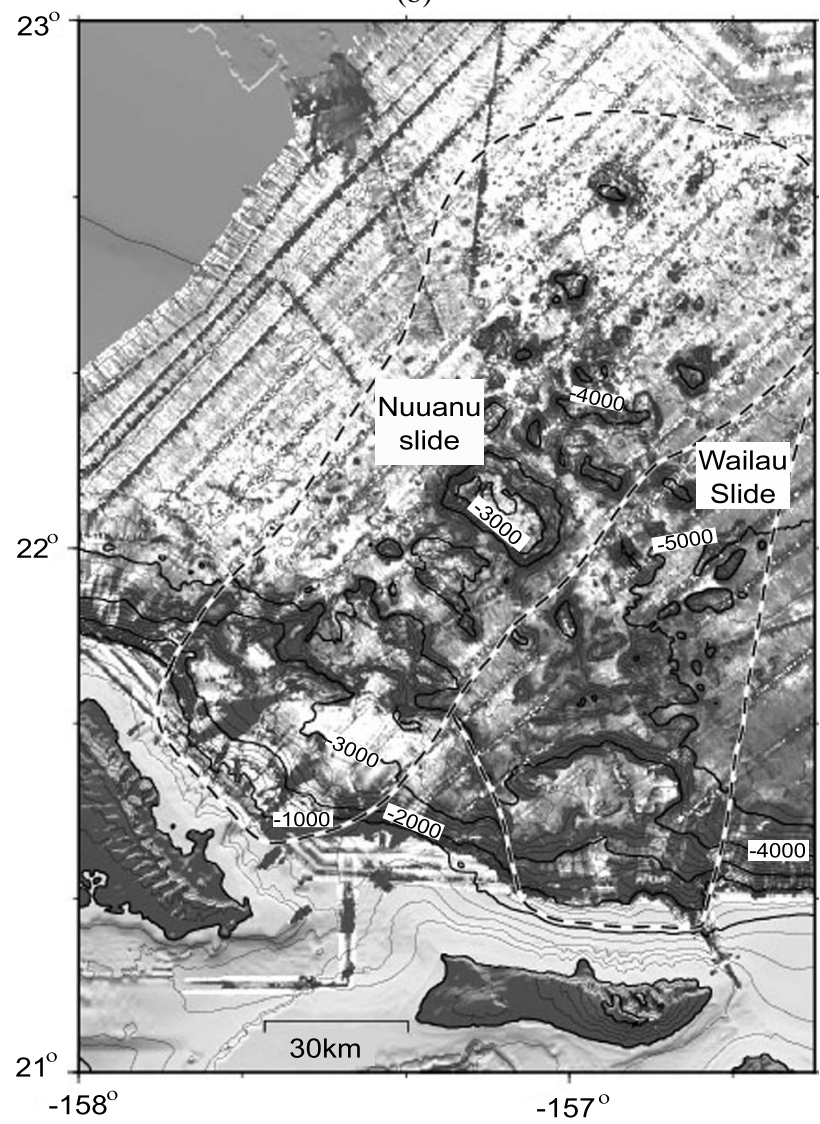

Fig. 16. (a) Simplified version of 1957 bathymetric data upon which Moore (1964) suggested the existence of giant submarine landslides in Hawaii. (b) Seabeam multibeam bathymetry of the north sides of Oahu and Molokai showing the Nuuanu and Wailau slides (Smith et al., 2002).

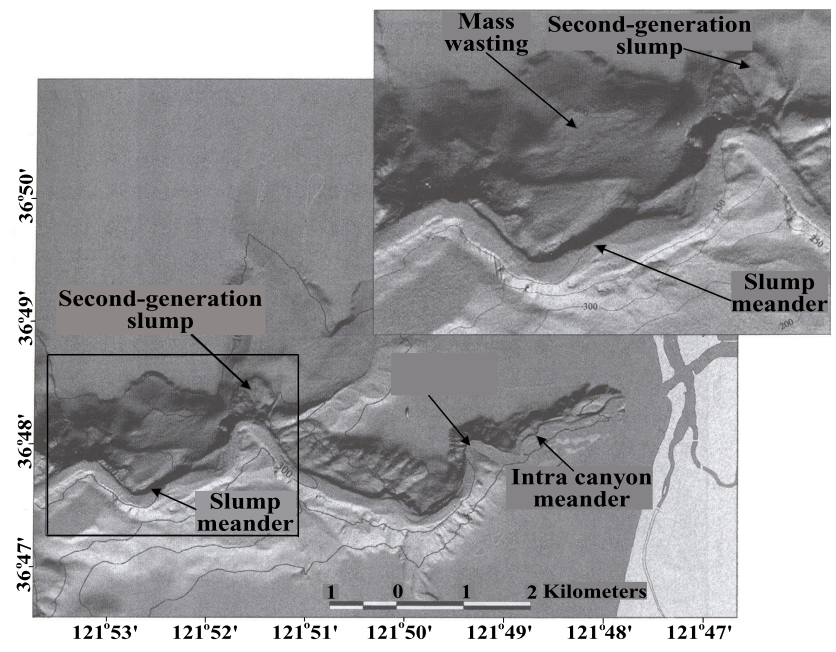

Fig. 17. Multibeam image of the headward part of Monterey canyon showing canyon and intra-canyon meanders, slump-produced meanders and mass-wasting associated with undercutting along the sides of the canyon axis. Expanded view of a slump meander and a well-defined second-generation slump resulting from erosion at the apex of a meander (Greene et al., 2002).

3. Giant Hawaiian landslides. When Lee (1989) was being written, long-range GLORIA sidescan-sonar surveys of the Hawaiian Exclusive Economic Zone (EEZ) were being completed, and the great areal extent of submarine slope failure deposits around the Hawaiian Islands was becoming fully appreciated (Moore et al., 1989). The existence of giant submarine landslides off the north coasts of Oahu and Molokai had been suggested previously (Moore, 1964), based on state-of-the-art bathymetric surveys from 1957 . These bathymetric charts (Fig. 16a), however, required considerable skill in interpretation and not all investigators agreed on a landslide origin for the features. The GLORIA images were a significant improvement, but they too, did not provide a very great level of resolution. In 1998 and 1999, deepwater multibeam surveys were conducted off the Nuuanu and Wailau landslide deposits (Smith et al., 2002, Fig. 16b) and these surveys show much finer details than could previously be observed. For example, 54 individual blocks larger in size than $1 \mathrm{~km}^{3}$ have been mapped in the Nuuanu landslide and the geometries of the irregularly shaped blocks are well enough known that they can be reassembled in "jigsaw puzzle fashion" (Moore and Clague, 2002). These new results can provide a much better basis for exploring the conditions that led to the catastrophic landslides and for estimating the characteristics of the tsunamis that the landslides certainly produced.

4. Submarine canyons. Multibeam imagery in submarine canyons has disclosed an environment commonly dominated by submarine landslide processes. For example, in Monterey Canyon (Fig. 17, Greene et al., 2000) the 
walls are typically covered by a variety of mass wasting features. In addition, the images show that landslides influence the development of the canyon. Undercutting at meanders can cause landslides to occur. The landslides, in turn, cause the development of new meanders, which undercut the opposite wall, generating secondgeneration landslides (Fig. 17).

\subsection{Improved dating}

Aside from submarine landslides that have clearly occurred in historic time, there has generally been an absence of reliable information on the age of landslide features. Rather, researchers have often made claims regarding the "freshness" of the appearance of acoustic records to speculate that the feature must be "young". Such vague interpretations cannot allow us to estimate landslide recurrence intervals and cannot form the basis for probabilistic risk analysis. Recently, some progress has been made in dating large prehistoric landslide features so that a better estimate of future events can be gained. An example is provided by the Palos Verdes debris avalanche (Normark et al., 2004).

The technique used to date landslide deposits is to sample normal sediment above and below clear landslide debris and determine the age using radiocarbon techniques. In the case of the Palos Verdes debris avalanche, Normark et al. (2004) obtained a piston core directly below the most distal large block of the debris avalanche (Fig. 18). Within the sampled sediment, the authors could identify deposits that likely resulted from flows of finer-grained debris emplaced during the debris avalanche. Radiocarbon dating of foraminifera contained in the piston core above and below the debris flow showed that the slope failure likely occurred about 7500 years B.P. Similar dating techniques, which have been applied elsewhere in southern California, indicate that the recurrence intervals for large submarine landslides (roughly $0.5 \mathrm{~km}^{3}$ or more) is on the order of several thousand years (Lee et al., 2004).

\section{Conclusions and future directions}

This brief review shows that much has been learned about submarine landslides over the last 15 years. Although the principle environments for submarine landslides still remain the same: fjords, deltas, canyons, volcanic islands and the open continental slope, much more information about the prevalence and morphologies of these features has become available. This is mainly the result of new mapping and profiling technologies that allow the production of images with the quality of aerial photographs. Other improved technologies such as remotely operated vehicles and current profilers have also helped to improve our state of knowledge.

With improved information about the seafloor, we have come to reassess the findings of some previous studies. For example, the large feature termed the "Humboldt Slide", located off northern California has been reinterpreted by some
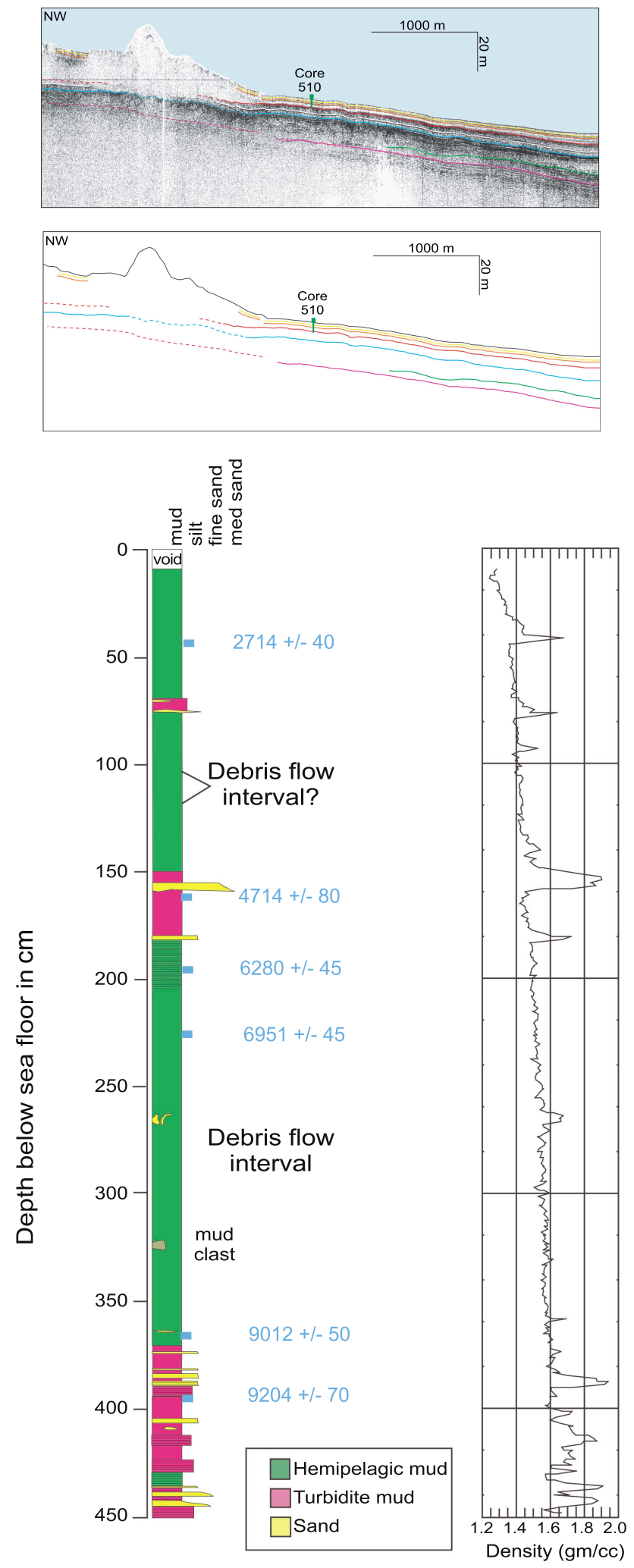

Fig. 18. The age of the Palos Verdes landslide is based on piston cores obtained immediately downslope from the toe of the deposit as shown in (a); radiocarbon dates (years B.P.) are shown between the lithologic and density logs in (b). 
as a field of sediment waves and not a landslide at all. The great tsunami resulting from a moderate earthquake in 1946 has been reconsidered as a possible example of landslide generation. In the case of the Papua New Guinea event of 1998, controversy has arisen over whether the tsunami could have resulted from earthquake effects alone or if a large earthquake-induced landslide was also needed.

Deep-sea trenches and lava deltas on volcanic islands are becoming recognized as environments in which landslides are common by virtue of the physical processes they are undergoing. The potential for landslide-tsunamis is becoming much better recognized as a hazard to coastal developments. Earlier landslide tsunamis, such as occurred in Alaska in 1964 and Commencement bay in 1894 are being reevaluated and the landslide deposits are being mapped using multibeam technology. Limited modeling of landslide motions is being undertaken.

Turbidity currents generated by landslides in the heads of submarine canyons are finally being monitored and evaluated in terms of measured bathymetry changes. Also, large landslide deposits on the seafloor are being dated so that the risk of damaging landslide-tsunamis to coastal developments can be determined.

Future directions need to include a better understanding of the transitions between landslides, sediment flows and turbidity currents. Also needed are more and better case histories with improved measurement of environmental parameters such as pore pressure. Models of sediment failure and flow need to have better ground truth and efforts to date existing features needs to be expanded. The roles of earthquake, hydrates and glacial cycles in causing sediment failure need to be better understood and modeled.

Acknowledgements. I would like to acknowledge the support of the US Geological Survey and the Office of Naval Research. I thank G. Greene, B. McAdoo, J. Locat, R. Kayen and J. Xu for very helpful reviews that greatly improved this manuscript.

Edited by: S. Tinti

Reviewed by: G. Greene, J. Locat, and B. McAdoo

\section{References}

Bohannon, R. G. and Gardner, J. V.: Submarine landslides of San Pedro Escarpment, southwest of Long Beach, California, Mar. Geol., 203, 261-268, 2004.

Bornhold, B. D., Ren, P., and Prior, D. B.: High-frequency turbidity currents in British Columbia fjords. Geo-Mar. Lett., 14, 238-243, 1994.

Butenko, J., Millliman, J. D., and Ye, Y.-C.: Geomorphology, shallow structure and geological hazards on the East China Sea, Cont, Shelf Res., 4, 121-142, 1985.

Canals, M., Lastras, G., Urgeles, R., Casamor, J. L., Mienert, J., Cattaneo, A., De Batist, M., Haflidason, H., Imbo, Y., Laberg, J. S., Locat, L., Long, D., Longva, O., Masson, D. G., Sultan, N., Trincardi, F., and Bryn, P.: Slope failure dynamics and impacts from seafloor and shallow sub-seafloor geophysical data: case studies from the COSTA project, Mar. Geol., 213, 9-72, 2004.
Carlson, P. R.: Holocene slump on continental shelf off Malaspina Glacier, Gulf of Alaska, Am. Assoc. of Petrol. Geologists Bull., 62, 2412-2425, 1978.

Clague, D. A. and Denlinger, R. P.: Role of olivine cumulates in destabilizing the flanks of Hawaiian volcanoes, Bull. Volcanol., 56, 425-434, 1994.

Clukey, E., Cacchione, D. A., and Nelson, C. H.: Liquefaction potential of the Yukon prodelta, Bering Sea: Proc., 12th Offshore Tech. Conf., Houston, TX, 315-325, 1980.

Coulter, H. W. and Migliaccio, R. R.: Effects of the earthquake of March 27, 1964 at Valdez, Alaska, US Geol. Survey Prof., Paper 542-C, 1966.

Dietrich, J. H.: Growth and persistence of Hawaiian rift zones, J. Geophys. Res., 93, 4258-4270, 1988.

Edwards, B. D., Lee, H. J., and Field, M. E.: Mudflow generated by retrogressive slope failure, Santa Barbara Basin, California Continental Borderland, J. of Sed. Res., A65, 57-68, 1995.

Eichhubl, P., Greene, H. G., and Maher, N.: Physiography of an active transpressive margin basin; high-resolution bathymetry of the Santa Barbara Basin, southern California continental borderland, Mar. Geol., 184, 95-120, 2002.

Field, M. E.: Sediment mass-transport in basins: controls and patterns, in: Short Course Notes Pacific Section, edited by: Douglas, R. G., Colburn, E. P., and Gorsline, D. S., SEPM, San Francisco, CA, 61-83, 1981.

Field, M. E., Gardner, J. V., Jennings, A. E., and Edwards, B. D.: Earthquake-induced sediment failures on a $0.25 \infty$ slope, Klamath River delta, Cal. Geol., 10, 542-546, 1982.

Field, M. E., Gardner, J. V., and Prior, D. B.: Geometry an significance of stacked gullies on the northern California slope, Mar. Geol., 154, 271-286, 1999.

Fryer, G. J., Watts, P., and Pratson, L. F.: Source of the great tsunami of 1 April 1946: a landslide in the upper Aleutian forearc, Marine Geology, 203, 201-218, 2004.

Gardner, J. V., Prior, D. B., and Field, M. E.: Humboldt slide a large shear-dominated retrogressive slope failure, Mar. Geol., 154, 323-338, 1999.

Gardner, J. V., Van den Ameele, E. J., Gelfenbaum, G., Barnhardt, W., Lee, H. J., and Palmer, S.: Mapping southern Puget Sound delta fronts after 2001 earthquake, Eos, Transactions, Amer. Geophys. Union, 82, 485, 488-489, 2001.

Gee, M. J. R., Gawthorpe, R. L., and Friedmann, J. S.: Giant striations at the base of a submarine landslide, Mar. Geol., 214, 287294, 2005.

Goff, J. A., Orange, D. L., Mayer, L. A., and Hughes-Clarke, J. E.: Detailed investigation of continental shelf morphology using a high resolution swath sonar survey: the Eel margin, northern California, Mar. Geol., 154, 255-270, 1999.

Gorsline, D. S., Kolpack, R. L., Karl, H. A., Drake, D. E., Fleischer, P., Thornton, S. E., Schwalbach, J. E., and Svarda, C. E.: Studies of fine-grained sediment transport processes and products in the California Continental Borderland, in: Fine-grained Sediments: Deep-Water Processes and Facies, edited by: Stow, D. A. V. and Piper, D. J. W., Oxford, Blackwell Scientific Publications, 395415, 1984.

Greene, H. G., Maher, N. M., and Paull, C. K.: Physiography of the Monterey Bay National Marine Sanctuary and implications about continental margin development, Mar. Geol., 181, 55-82, 2002.

Greene, H. G., Murai, L. Y., Watts, P., Maher, N. A., Fisher, M. A., Paull, C. E., and Eichhubl, P.: Submarine landslides of the Santa Barbara Basin: potential tsunami generators, Nat. Hazards Earth 
Syst. Sci., accepted, 2005.

Hampton, M.: The role of subaqueous debris flow in generating turbidity currents, J. of Sed. Petr., 42, 775-993, 1972.

Hampton, M. A., Lee, H. J., and Locat, J.: Submarine landslides, Revs. of Geophy., 34, 33-59, 1996.

Hampton, M. A., Lemke, R. W., and Coulter, H. W.: Submarine landslides that had a significant impact on man and his activities: Seward and Valdez, Alaska, in: Submarine Landslides: Selected Studies in the US EEZ: USGS Bull., edited by: Schwab, W. C., Lee, H. J., and Twichell, D. C., 2002, 123-142, 1993.

Holcomb, R. T. and Searle, R. C.: Large landslides from oceanic volcanoes, Mar. Geotech., 10, 19-32, 1991.

Hughes Clarke, J. E., Mayer, L. A., and Wells, D. E.: Shallow-water imaging multibeam sonars: A new tool for investigating seafloor processes in the coastal zone and on the continental shelf, Mar. Geophys. Res., 18, 607-629, 1996.

Iverson, R. M.: Can magma-injection and groundwater forces cause massive landslides on Hawaiian volcanoes?, J. of Volcan. and Geoth. Res., 66, 295-308, 1995.

Kachadoorian, R.: Effects of the earthquake of 27 March 1964 at Whittier, Alaska, US Geol. Survey Prof., Paper 542-B, 1965,

Karl, H. A. and Carlson, P. R.: Alaskan EEZ, in: Geology of the Unted States' Seafloor: The View From GLORIA, edited by: Gardner, J. V., Field, M. E., and Twichell, D. C., Cambridge University Press, Cambridge, 251-254, 1996.

Lee, H. J.: Undersea landslides: extent and significance in the Pacific Ocean, in: Landslides, extent and economic significance, edited by: Brabb, E. E. and Harrod, B. L., Proc. of the 28th Inter. Geol. Cong.: symposium on landslides, Washington, D.C., 367-380, 1989,

Lee, H. J. and Edwards, B. D.: Regional method to assess offshore slope stability, J. Geotech. Eng., 112, 489-509, 1986.

Lee, H. J., Kayen, R. E., Gardner, J. V., and Locat, J.: Characteristics of several tsunamigenics submarine landslides, in: Submarine Mass Movements and their Consequences, edited by: Locat, J. and Mienert, J., Kluwer, The Netherlands, 357-366, 2003.

Lee, H. J., Normark, W. R., Fisher, M. A., Greene, H. G., Edwards, B. D., and Locat, J.: Timing and extent of submarine landslides in Southern California. Proceedings, Offshore Technology Conference, Houston TX, OTC Paper 16744, 2004.

Lee, H. J., Syvitski, J. P. M., Parker, G., Orange, D., Locat, J., Hutton, J. W. H., and Imran, J.: Distinguishing sediment waves from slope failure deposits: field examples, including the "Humboldt Slide" and modeling results, Mar. Geol., 192, 79-104, 2002.

Lemke, R. W.: Effects of the earthquake of 27 March 1964, at Seward, Alaska, US Geol. Survey Prof., Paper 542-E, 1967,

Lewis, K. B. and Pantin, H. M.: Channel-axis, overbank and drift sediment waves in the southern Hikurangi Trough, New Zealand, Mar. Geol., 192, 123-152, 2002.

Liang, Y.-B. and Lu, B.: Acoustic environment and physicomechanical properties of the shelf seabed off the Pearl River mouth, Mar. Geotech., 6, 377-392, 1986.

Lipman, P. W., Normark, W. R., Moore, J. G., Wilson, J. B., and Gutmacher, C. E.: The giant Alika debris slide, Mauna Loa, Hawaii, J. of Geophys. Res., 93, 4279-4299, 1988.

Locat, J., Gardner, J. V., Lee, H., Mayer, L., Hughes-Clarke, J. E., and Kammerer, I.: Using multibeam sonar surveys for submarine landslide investigations, Proc. of the Intern. Symp. on Slope Stability Eng., Shikoku, Japan, 127-134, 1999.

Locat, J., Lee, H. J., Locat, P., and Imran, J.: Numerical analysis of the mobility of the Palos Verdes debris avalanche, California, and its implication for the generation of tsunamis, Mar. Geol.,
203, 269-280, 2004.

Luternauer, J. L. and Finn, W. D. L.: Stability of the Fraser River delta front, Can. Geotech. J., 20, 603-616, 1983.

Marsset, T., Barsset, B., Thomas, Y., Cattaneo, A., Thereau, E., Trincardi, F., and Cochonat, P.: Analysis of Holocene sedimentary features on the Adriatic self from 3D very high resolution seismic data (Triad survey), Mar. Geol., 213, 73-90, 2004.

Mattox, T. N. and Mangan, M. T.: Littoral hydrovolcanic explosions: a case study of lava-seawater interaction at Kilauea, J. of Volcan. and Geotherm. Res., 75, 1-17, 1997.

McAdoo, B. G., Capone, M. K., and Minder, J.: Seafloor geomorphology of convergent margins: implications for Cascadia seismic hazard, Tectonics, 23, TC6008, 15, 2004

McAdoo, B. G., Pratson, L. F., and Orange, D. L: Submarine landslide geomorphology, US continental slope, Mar. Geol., 169, 103-136, 2000.

Milliman, J. D. and Meade, R. H.: World-wide delivery of river sediment to the oceans, J. of Geol., 91, 1-21, 1983.

Moore, J. G.: Giant Submarine Landslides on the Hawaiian Ridge, US Geological Survey Professional Paper 501-D, 1964.

Moore, J. G. and Clague, D. A.: Mapping the Nuuanu and Wailau landslides in Hawaii, in: Hawaiian Volcanoes: Deep Underwater Perspectives, edited by: Takahashi, E., Lipman, P. W., Garcia, M. O., Naka, J., and Aramaki, S., Geophys. Mono. 128, Amer. Geophys. Union, Washington, D.C., 223-244, 2002.

Moore, J. G., Clague, D. A., Holcomb, R. T., Lipman, P. W., Normark, W. R., and Torresan, M. E.: Prodigious submarine landslides on the Hawaiian Ridge, J. Geophys. Res., 94, 1746517484, 1989.

Morgan, J. K. and Clague, D. A.: Volcanic spreading on Mauna Loa volcano, Hawaii: Evidence from accretion, alteration, and exhumation of volcaniclastic sediments, Geol., 31, 411-414, 2003.

Murty, T. S.: Submarine slide-generated water waves in Kitimat Inlet, British Columbia, J. Geophys. Res., 84, 7777-7779, 1979.

Nittrouer, C. A. and Kravitz, J. H.: STRATAFORM; A program to study the creation and interpretation of sedimentary strata on continental margins, Oceanography, 9, 146-152, 1996.

Nittrouer, C. A. and Sternberg, R. W.: The formation of sedimentary strata in an allochthonous shelf environment: the Washington continental shelf, Mar. Geol., 42, 201-232, 1981.

Normark, W. R., Moore, J. G., and Torresan, M. E.: Giant volcanorelated landslides and the development of the Hawaiian Islands, in: Submarine Landslides: Selected Studies in the US Exclusive Economic Zone, edited by: Schwab, W. C., Lee, H. J., and Twichell, D., USGS Survey Bulletin 2002, 184-196, 1993.

Normark, W. R., McGann, M., and Sliter, R.: Age of Palos Verdes submarine debris avalanche, southern California, Mar. Geol., 203, 247-260, 2004.

Okal, E. E., Plafker, G., Synolakis, C. E., and Borrero, J. C.: Nearfield survey of the 1946 Aleutian tsunami on Unimak and Sanak Islands, Bull. of the Seis. Soc. of Am., 93, 1226-1234, 2003.

Orange, D.: Tectonics, sedimentation, and erosion in northern California: submarine geomorphology and sediment preservation potential as a result of three competing processes, Mar. Geol., 154, 369-382, 1999.

Paull, C. K., Ussler, W., III, Greene, H. G., Keaten, R., Mitts, P., and Barry, J.: Caught in the act: the 20 December 2001 gravity flow event in Monterey Canyon, Geo-Mar. Lett., 22, 227-232, 2003.

Paull, C. K., Mitts, P.,, Ussler, W., III, Keaten, R., and Greene, H G.: Trail of sand in upper Monterey Canyon: Offshore California, GSA Bull., 117, 1134-1145, 2005. 
Plafker, G., Kachadoorian, R., Eckel, E. B., and Mayo, L. R.: Effects of the earthquake of March 27, 1964 on various communities, US Geol. Survey Prof., Paper 542-G, 1969.

Prior, D. B., Bornhold, B. D., Coleman, J. M., and Bryant, W. R.: Morphology of a submarine slide, Kitimat Arm, British Columbia, Geol., 10, 588-592, 1982a.

Prior, D. B., Bornhold, B. D., and Johns, M. W,: Active sand transport along a fjord-bottom channel, Bute Inlet, British Columbia, Geol., 14, 581-584, 1986.

Prior, D. B., Bornhold, B. D., Wiseman, W. J., and Lowe, D. R.: Turbidity current activity in a British Columbia flord, Science, 237, 1330-1333, 1987.

Prior, D. B., Coleman, J. M., and Bornhold, B. D.: Results of a known sea-floor instability event, Geomar. Lett., 2, 117-122., 1982b.

Ranero, C. R., von Huene, R., Flueh, R. E., Duarte, M., Baca, D., and McIntosh, K.: A cross section of the convergent Pacific margin of Nicaragua, Tectonics, 19, 335-357, 2000.

Schwab, W. C. and Lee, H. J.: Geotechnical analyses of submarine landslides in glacial marine sediment, northeast Gulf of Alaska, in: Glacial Marine Sedimentation, edited by: Molnia, B. F., Plenum press, New York, 145-184, 1983.

Schwab, W. C., Lee, H. J., and Molnia, B. F.: Causes of varied sediment gravity flow types on the Alsek prodelta, northeast Gulf of Alaska, Mar. Geotech., 7, 317-342, 1987,

Smith, D. P., Ruiz, G., Kvitek, R., and Iampietro, P. J.: Semiannual patterns of erosion and deposition in upper Monterey Submarine Canyon from serial multibeam bathymetry, GSA Bull., 117, 1123-1133, 2005.

Smith, J. R., Satake, K., and Suyehiro, K.: Deepwater multibeam sonar surveys along the southeastern Hawaii Ridge: guide to the CD-ROM, in: Hawaiian Volcanoes: Deep Underwater Perspectives, edited by: Takahashi, E., Lipman, P. W., Garcia, M. O., Naka, J., and Aramaki, S., Geophys. Mono. 128, Amer. Geophys. Union, Washington, D.C., 3-9, 2002.

Synolakis, C. E., Bardet, J-P, Borrero, J. C., Davies, H. L., Okal, E. A., Silver, E. A., Sweet, S., and Tappin, D. R.: The slump origin of the 1998 Papua New Guinea tsunami, Proc., Royan Society, Mathematical, Physical and Engineering Sciences, 458, 763-789, 2002.
Syvitski, J. P. M.: ADFEX: An international effort to generate and monitor the dynamics of mesoscale slides, Abstracts of the 29th International Geological Congress, Kyoto, Japan, 3, 936, 1992.

Syvitski, J. P. M. and Farrow, G. E.: Structures and processes in bayhead deltas: Knight and Bute Inlet, British Columbia, Sed. Geol., 36, 217-244, 1983.

Tappin, D. R. (Ed.): Special issue; submarine-slump generated tsunamis, Mar. Geol., 203, 199-380, 2004.

Tappin, D. R., Watts, P., and Matsumoto, T.: Architecture and failure mechanism of the offshore slump responsible for the 1998 Papua New Guinea tsunami, in: Submarine Mass Movements and their Consequences, edited by: Locat, J. and Mienert, Kluwer Academic Publishers, The Netherlands, 383-389, 2003.

Tappin, D. R., Watts, P., McMurtry, G. M., Lafoy, Y., and Matsumoto, T.: The Sissano, Papua-New Guinea tsunami of July 1998-offshore evidence on the source mechanism, Mar. Geol., 175, 1-24, 2001.

von Huene, R. Ranero, C. R., and Watts, P.: Tsunamigenic slope failure along the Middle America Trench in two tectonic settings, Mar. Geol., 203, 303-317, 2004.

Wynn, R. B. and Stow, D. A. V.: Classification and characterization of deep-water sediment waves, Mar. Geol., 192, 7-22, 2002.

Wynn, R. B., Weaver, P. P. E., Ercilla, G., Stow, D. A. V., and Masson, D. G.: Sedimentary processes in the Selvage sedimentwave field, NE Atlantic; new insights into the formation of sediment waves by turbidity currents, Sedimentology, 47, 11811197, 2000.

Xu, J. P., Noble, M. A., and Rosenfeld, L. K.: In-situ measurements of velocity structure within turbidity currents, Geophys. Res. Lett., 31, L09311, doi:10.1029/2004GL019718, 2004.

Yalciner, A. C., Pelinovshi, E. N., Okal, E., and Synolakis, C. E.: Submarine landslides and Tsunamis, proceedings of the NATO Advanced Research Workshop on Underwater Ground Failures on Tsunami Generation, Modeling, Risk and Mitigation, Istanbul, Turkey, 23-26 May 2001, Kluwer Academic Publishers, Dordrecht, the Netherlands, 328, 2003. 